\title{
A conjunção et na definição ciceroniana de populus ${ }^{1}$
}

\author{
Luiz Marcos da Silva Filho \\ Professor de História da Filosofia Medieval na UFLA
}

\begin{abstract}
Resumo: Trata-se de investigar o papel desempenhado pela conjunção et na definição ciceroniana de populus: "Povo [...] é a união de inumeráveis homens associados por assentimento de direito e utilidade comum". Tal partícula ou bem cumpre função aditiva, ou bem consecutiva, de forma que a questão a ser respondida é: "assentimento de direito" e "utilidade comum" são constituídos simultaneamente na fundação da res publica ou há anterioridade condicionante de um em relação ao outro?
\end{abstract}

Palavras-chave: res publica, populus, justiça, utilidade comum, estoicismo.
Abstract: This study investigates the role played by the conjunction et in the Ciceronian definition of populus: "people [...] is an assemblage of innumerable people associated by a juridical consent and a common utility". This particle fulfills either an additive or a consecutive function: are "juridical consent" and "common utility" simultaneously constituted in the res publica's foundation or is there a conditioning anteriority between one another?

Keywords: res publica, populus, justice, common utility, stoicism.

"Povo é não toda união de homens de qualquer modo congregados, mas a união de inumeráveis homens associados por assentimento de direito e utilidade comum"2. Tal definição de Cícero,

1. Somos gratos às sugestões dos leitores das versões preliminares do artigo: Alberto Barros, Alfredo Storck, Carlos Eduardo de Oliveira, Clóvis Luiz Alonso Júnior, Cristiane Negreiros Abbud Ayoub, Elis Joyce Gunella, José Carlos Estêvão, Moacyr Novaes e Guy Hamelin. O texto, com poucas modificações, é originalmente o capítulo I, "Sobre o fundamento naturalista da política em De re publica, de Cícero", de nossa tese de doutoramento: SILVA FILHO, L. M. Desnaturalização da política n'A cidade de Deus, de Agostinbo. São Paulo. 154 p. Tese de Doutorado em Filosofia. Universidade de São Paulo. 2012.

2. "[...] populus [autem] non omnis bominum coetus quoquo modo congregatus, sed coetus multitudinis iuris consensu et utilitatis communione sociatum". CICERO. De re publica, 
após dizer o que "povo" não é, apresenta três condições para que um conjunto de homens constitua "povo": 1) constituir multitudo, 2) compartilhar o mesmo ius e 3) restringir o útil ao que for comum ou público. Desse modo, para que uma multitudo adquira o estatuto de populus e os homens que a compõem, o de cives, eles devem constituir consensus iuris et utilitatis communio. Assim, a investigação do fundamento da política em De re publica implica compreender cada uma das condições presentes na definição de "povo", bem como a relação entre elas estabelecida pela conjunção et: desempenharia et função aditiva ou consecutiva? Mais precisamente, "assentimento de direito" e "utilidade comum" são condições cumpridas simultaneamente na edificação da civitas ou a existência de uma é condição precedente da outra? Para responder, primeiro reconstituiremos o itinerário argumentativo de Cícero ao elaborar a definição; depois, cada uma das condições será examinada a partir de certo estoicismo que Cícero assume nas obras morais tardias (De re publica, De legibus, De officiis) e que concederá compreensão da articulação entre uma e a outra.

\section{Optimus status civitatis}

Em De re publica, o principal propósito de Cícero é encontrar forma de governo capaz de conferir perpetuidade à res publica. Para tanto, a investigação se dá a partir da teoria aristotélico-polibiana da anaciclose, com especial atenção aos traços de geração e de corrupção de cada uma das formas de governo: monarquia-tirania, aristocracia-oligarquia, democracia-oclocracia. A constituição de governo de uma res publica ${ }^{3}$ tem origem na necessidade de ela ser dirigida ou por um único governante (monarquia) ou por alguns homens virtuosos (aristocracia) ou por todos os cidadãos (democracia). Essas formas, contudo, são perecíveis: na monarquia, os mais virtuosos e o povo são

I, xxv, 39 (Grifo nosso). As traduções de "iuris consensus" e "utilitatis communio" procuraram preservar mais o significado do que a proximidade de signos entre o latim e o português. A tradução de "consensus" por "assentimento", e não por "consenso" ou "consentimento", guarda maior rigor na medida em que remete à adesão a direito que o homem reconhece em sua natureza a partir de processo intelectivo da alma e não por meio de acordo ou contrato instituído a posteriori. Todas as traduções são de nossa responsabilidade.

3. Em Cícero, o conceito de res publica é equívoco: guarda tanto o sentido geral de civitas quanto o específico de optimus status civitatis. 
privados das deliberações públicas; na aristocracia, o povo igualmente é privado; na democracia, ainda que todos tenham participação na potestas, a equidade se torna iniquidade, pois a dignitas de cada cidadão é desprezada, porque todos são considerados iguais, sem distinção da excelência de uns em relação a outros ${ }^{4}$.

Por consequência, a dissensão é iminente em cada uma das formas puras de governo, também ameaçadas pela possibilidade de os governantes padecerem de paixões e sobreporem o privado sobre o público 5 . A instabilidade, desse modo, corrompe as formas de governo positivas e transforma-as em suas correspondentes negativas ${ }^{6}$. A monarquia se torna tirania; a aristocracia, oligarquia; a democracia, governo da turba $^{7}$ (oclocracia, para manter a expressão polibiana).

A partir de tal investigação, Cícero elabora o optimus status civitatis: forma de governo perpétua, porque temperada, porque assimila as qualidades de cada uma das constituições puras "positivas" de governo. A elaboração, por conseguinte, é a de "um quarto gênero de república, que deve ser o mais estimado porque constituído a partir da mescla e da moderação daqueles três primeiros ${ }^{1 / 8}$. O governo misto é a melhor constituição na medida em que não padece das instabilidades daquelas formas positivas, já que reúne as qualidades de cada uma delas. "Ora, existe em uma república algo de expeditivo e régio, existe uma coisa concedida e consagrada à autoridade dos mais virtuosos, e algumas reservadas ao juízo e à vontade da multidão" . Nesse sentido, a constituição mista é justa (uma vez que as "jurisdições" da res publica são concedidas aos cidadãos aos quais devidamente cabem), guarda estabilidade e durabilidade (firmitas). Dotado dessas características, o

4. Cf. CICERO. De re publica, I, xxvii, 43; I, xxxiv, 53.

5. Cf. Idem, I, xxvii, 43.

6. Cf. Idem, I, xxix, 45.

7. "[...] sequenza che Norberto Bobbio, in un corso dedicato specificamente alla teoria delle forme di governo, ba sintetizzato in simboli nella formula $+-+-+-{ }^{\prime}$. REVELLI, M. Cicerone, Sant'Agostino, San tommaso. Torino: G. Giappichelli Editore, 1989, p. 62.

8. "[...] quartum quoddam genus rei publicae maxime probandum esse [sentio], quod est ex bis quae prima dixi moderatum et permixtum tribus.". CICERO. De re publica., I, xxix, 45.

9. "[placet] enim esse quiddam in re publica praestans et regale, esse aliud auctoritati principum inpartitum ac tributum, esse quasdam res servatas iudicio voluntatique multitudinis.". Idem, I, xlv, 69. 
optimus status civitatis escapa daquele circuito de geração e de corrupção de formas de governo ${ }^{10}$.

Todavia, que exatamente permanece primordial e duradouro na constituição mista e perece em todas as outras formas de governo? Decerto não é a potestas, pois esta não é eminente em todas as formas de governo: na aristocracia, por exemplo, a potestas não pode ser equiparada à auctoritas; na democracia, nem a potestas nem a auctoritas guardam a excelência da libertas. Trata-se de vislumbrar o que uma res publica deve guardar como condição para não deixar de ser uma res publica, o que exatamente se encontra presente em todo e qualquer status civitatis.

\section{A definição de populus}

A tarefa é definir o termo em questão, pois na definição de res publica se encontrará o seu princípio de edificação e permanência. Cícero dá prosseguimento à tarefa: "res publica é coisa do povo"11. Etimologicamente o termo "república" significa certo bem $\left(\right.$ res $\left.^{12}\right)$, bem comum, no qual todo o povo tem participação. Assim, a definição de "república" exige, por sua vez, a definição de "povo", uma vez que precisamos descobrir o que é "povo" para saber o que ele guarda como bem (res) para si: "populus é não toda união de homens de qualquer modo congregados, mas a união de inumeráveis homens associados

10. A análise do circuito de geração e de corrupção de formas de governos presente no livro I Da república é mais lógica ou formal do que histórica, porquanto o conteúdo histórico do circuito varia de república para república, bem como o acontecimento de ruptura com o ciclo, por meio do acontecimento da constituição mista. O conteúdo histórico que interessa a Cícero é, claro, o da História de Roma, cuja narração e investigação encontram-se no livro II da obra. Realizamos estudo mais pormenorizado sobre o livro II no capítulo I, "Res gestae e res publica em Cícero", de nossa dissertação de mestrado: SILVA FILHO, L. M. A definição de populus n'A cidade de Deus de Agostinbo: uma controvérsia com Da república de Cícero. São Paulo. 205 p. Dissertação de Mestrado em Filosofia. Universidade de São Paulo. 2008.

11. "[...] res publica res populi". CICERO. De re publica, I, xxv, 39.

12. A amplitude semântica de res concede sua compreensão para muito além de "coisa". Decerto, a res que precisa ser preservada para que o público seja resguardado é "bem" do povo. 
por assentimento de direito e utilidade comum"13. Disso, podemos dizer que, para constituir populus, um conjunto de homens deve formar multitudo que, necessariamente, resguarde o direito ${ }^{14}$ e a utilidade comuns.

As duas condições cujas expressões são articuladas pela conjunção et constituem, afinal, a res de um populus, a res populi? Se sim, na definição de populus já se encontra a de res publica, e de fato esta parece implicar aquela. Desse modo, o que a definição de populus expressa é o retroverso da de res publica. Melhor dizendo, se res publica é res populi, populus é coetus multitudinis re sociatus: aí, bem como em res publica, res substituiria e conteria iuris consensus e utilitatis communio. Por conseguinte, a definição de res publica e a de populus são intercambiáveis, uma se encontra implicada na outra e em reciprocidade uma desdobra a outra: não há "república" sem "povo", nem "povo" sem "república", a fundação e a ruína de um são simultaneamente as do outro.

\section{Sobre a conjunção et}

Retornemos à questão inicial, porém agora cientes de que o povo que cumprir perpetuamente as duas condições necessárias cujas expressões são articuladas pela conjunção et constituirá não qualquer república, mas "a melhor forma de república". Tal dado não é acessório, pois revela que a perpetuidade histórica da associação por "assentimento de direito" e "utilidade comum" resulta da constituição mista e nela tem lugar privilegiado. Isso, todavia, ainda não responde à pergunta inicial. Afinal, tanto é possível afirmar que o optimus status civitatis é edificado pela simultânea fundação e preservação do "assentimento de direito" e da "utilidade comum", quanto é possível dizer que há o estabelecimento, primeiro, de associação entre homens por "assentimento de direito" e, em sequência, por "utilidade comum". Nesse caso, teríamos de considerar que a civitas experimentaria dois momentos de fundação e que antes do cumprimento do segundo

13. "[...] populus [autem] non omnis bominum coetus quoquo modo congregatus, sed coetus multitudinis iuris consensu et utilitatis communione sociatus.". CICERO. De re publica, I, xxv, 39 (Grifo nosso).

14. "In Cicerone [...] l'elemento giustizia si pone costitutivo del politico, come conditio sine qua non." REVELLI, M. Cicerone, Sant'Agostino, San tommaso, p. 26. Em Cícero, ius e iustitia são indissociáveis. 
existiria algo como meia civitas, ou uma civitas em fundação, se é que poderíamos denominá-la civitas.

Longa passagem do livro III da obra De re publica parece iluminar o problema.

A verdadeira lei é a razão reta, conforme a natureza, difundida em todos, inquebrantável, eterna, que ordenando chama ao dever, proibindo, desvia do erro; todavia, nem ordena nem proíbe em vão aos probos, nem move os ímprobos ordenando ou proibindo. Não é fás que essa lei incida em ob-rogação, nem que seja derrogada, nem ab-rogada; tampouco podemos ser isentados dessa lei pelo senado ou pelo povo, e também não devemos procurar outro comentador ou intérprete dela; nem existirá uma lei em Roma, outra em Atenas, uma agora, outra depois, mas apenas uma única lei, eterna e imutável, abrangerá todos os povos e todo o tempo, e deus será o único, por assim dizer, mestre e imperador de todos: autor, juiz e promulgador dessa lei. Quem não a cumprir se afastará da própria natureza de homem e rejeitará essa natureza; por isso, sofrerá as maiores punições. ${ }^{15}$

\section{Iuris consensus}

Antes de esgotar todos os conceitos dispostos na citação acima, interessa observar certa relação entre "divindade", "natureza", "lei/direito", "razão" e "cidade". A vera lex, imutável e eterna, revela concepção de ius naturale, que parece confundir-se com ius universi ${ }^{16}$. Em doutrina estoi$\mathrm{ca}^{17}$, identificar "natureza" e "universo" significa afirmar traço sagrado

15. "[...] est quidem vera lex recta ratio, naturae congruens, diffusa in omnes, constans, sempiterna, quae vocet ad officium iubendo, vetando a fraude deterreat, quae tamen neque probos frustra iubet aut vetat, nec improbos iubendo aut vetando movet. Huic legi nec obrogari fas est, neque derogari aliquid ex bac licet, neque tota abrogari potest, nec vero aut per senatum aut per populum solvi bac lege possumus, neque est quaerendus explanator aut interpres eius alius, nec erit alia lex Romae, alia Atbenis, alia nunc, alia posthac, sed et omnes gentes et omni tempore una lex et [ut] sempiterna et immutabilis continebit, unusque erit communis quasi magister et imperator omnium deus: ille legis buius inventor, disceptator, lator, cui qui non parebit, ipse se fugiet, ac naturam bominis aspernatur boc ipso luet maximas poenas".

CICERO. De re publica, III, xxii, 33.

16. Cf. CICERO. De legibus, I, iv, 14 ss.

17. A leitura de um Cícero estoico, sem dúvida, é polêmica. Defendemo-la, porém, a partir de Barros, Grimal, Poschl, Revelli, Watson, entre outros. 
de todo o cosmo. Com efeito, a Razão universal $\left(\log o s\right.$, ignis $\left.^{18}\right)$ gera e preenche toda a natureza ordenando-a segundo "plano racional"19. $\mathrm{O}$ ser humano, como particula da perfeição que é a natureza, contém em si a Lei e cumpre-a segundo certo instinto natural ou bormê: espontaneidade cujo descumprimento significa rejeição da própria natureza ${ }^{20}$.

Compreende-se, dessa maneira, por que Cícero diz que "não há coisa alguma na qual a virtude humana se aproxime mais do nume dos deuses do que o fundar novas cidades ou conservar as já fundadas" ${ }^{\prime \prime 21}$. O cumprimento do direito natural se dá por meio da fundação e da re-fundação de cidades, e nisso reside possibilidade de imitação humana do divino ${ }^{22}$. Assim, na medida em que aos deuses cumpre a gênese da natureza, aos homens cumpre a fundação de civitates e de todas as instituições relacionáveis a elas, bem como o invento de artefatos que se ponham em função delas, de acordo, porém, com plano racional que atravessa todo o cosmo. Eis por que "o ius a que se refere o iuris consensus da definição de res publica seja o ius naturale"23, do qual decorre todo o ius civitatis.

Watson, por exemplo, diz que "the leading proponent of the importance of the development of a law for all men is Cicero. And the main source for the ideas of Cicero on this matter was Stoic pbilosopby". WATSON, G. The Natural Law and Stoicism. In: LONG, A. A. Problems in Stoicism. London: The Athlone Press, 1996, p. 225. No mundo romano, Agostinho, por exemplo, compreendia Cícero, antes de tudo, próximo do estoicismo: "Cicero in pluribus fuisse Stoicum quam veterem Academicum vult videri." AUGUSTINUS. De civitate dei, XIX, iii, 2.

18. Cf. CICERO. De natura deorum, II, xxii.

19. "[...] un piano razionale". REVELLI, M. Op. cit., p. 47.

20. "C'est à partir de cet instinct (manifestation, peut-être, de la Raison universelle, c'est-à-dire de l'ordre et de la finalité que l'on découvre dans la création, mais antérieurs à la conscience que peut en prendre l'esprit bumain) que se déduisent les différentes formes de gouvernement." GRIMAL, P. Cicéron. France: Librairie Arthème Fayard, 1986, p. 261. Sobre a reflexão e traduções que Cícero faz de hormê, cf. De natura deorum, II, xxii.

21. "[...] neque [enim ] est ulla res in qua propius ad deorum numen virtus accedat bumana, quam civitatis aut condere novas aut conservare iam conditas." CICERO. De re publica, I, vii, 12.

22. Cf. GRAMMATICO, G. El príncipe como espejo del dios en La República de Cicerón. In: ARBEA, A.; GRAMMATICO, G.; CAJAS, H. H. Cicerón, un alma ardiente. Santiago: Editorial Universitaria, 1994.

23. "Lo ius cui si riferisce lo iurus consensus della [sua] definizione di res publica, è lo ius naturale." REVELLI, M. Cicerone, Sant'Agostino, San tommaso, pp. 27-28. 
Finalmente é compreensível a caracterização do optimus status civitatis como aquele que alcançar perpetuidade. Ora, uma diuturna res publica é obra dotada de imortalidade: característica divina. A investigação acerca da melhor forma de governo é, pois, a procura de forma excelente de cidade na qual e pela qual o homem possa melhor realizar sua bumanitas ${ }^{24}$ e, desse modo, "produzir na natureza, por assim dizer, uma segunda natureza"25. Como visto, a virtude da justiça é no mínimo conditio sine qua non de uma república, de forma que uma constituição política que padeça de instabilidade e de corrupção é cidade em ruínas, cujos cidadãos não lograram o cumprimento da natureza, da razão e do direito, isto é, do ius naturale ou universi.

\section{Utilitatis communio}

O fracasso da tarefa humana de empreender civitates explicita, contudo, não apenas descumprimento da virtude da justiça, expresso pelo não estabelecimento ou pela cisão do iuris consensus, mas também malogro da outra condição: a "utilidade comum". A entender tal condição como "utilidade pública", "comum", em detrimento de "utilidade privada", "assentimento de direito" pode ser estabelecido sem obscurecimento de "utilidade privada"? Inversamente, o obscurecimento de "utilidade privada", em proveito da "utilidade pública", pode ser estabelecido sem "assentimento de direito"? O problema, mais uma vez, é recolocado, mas agora em terreno estoico, em que iuris consensus e utilitatis communio devem ser entendidos.

É notável que a realização da natureza humana por meio da fundação e/ou da preservação de civitates subentende que a vida por excelência do ser humano seja a pública: "Esta é a razão do opróbrio lançado [...] sobre toda a esfera da vida privada, cuja 'idiotice' consistia em preocupar-se exclusivamente com a sobrevivência" ${ }^{\prime 26}$. Ora, os homens, ao contrário das bestas, distinguem-se por meio da capacidade de imitar os deuses pela imortalidade. O traço imorredouro dos feitos humanos pressupõe, todavia, a existência de um locus: "um es-

24. Cf. VEYNE, P. Humanitas: romanos e não romanos. In: GIARDINA, A. O bomem romano. Lisboa: Presença, 1992.

25. "[...] in $[\ldots]$ natura quasi alteram naturam efficere". CICERO. De natura deorum, II, $1 \mathrm{x}$.

26. ARENDT, H. Entre o passado e o futuro. Trad. Barbosa, M. W. São Paulo: Perspectiva, 2003, p. 104. 
paço imperecível garantindo que o 'imortalizar' não fosse em vão"27. Tal locus é a res publica, Roma, edificada pelos grandes varões da história romana (Brutus, Cipião Nasica, Torquato, Sévola, Paulo Emílio...) que sacrificaram benefícios privados, incluída a própria vida. Por consequência, a utilitatis communio é necessariamente elemento constitutivo da res publica e inexistente na ausência do iuris consensus, que delimita as fronteiras do público/comum.

\section{Iuris consensus et utilitatis communio}

Desse modo, "assentimento de direito" e "utilidade comum" são duas condições cujo cumprimento, para que exista populus, deve ser simultâneo. Afinal, é impossível um conjunto de homens estabelecer antes "assentimento de direito" e, depois, "utilidade comum". Consoante a asserção de que o cumprimento da vera lex se dá por meio da fundação e/ou da preservação de civitates, qualquer ato fundador estabelece, a um só tempo, iuris consensus e utilitatis communio. Ora, se o ius de iuris consensus é o ius naturale, ele é a estrita observância da vera lex, e seu cumprimento exige mesmo a utilitatis communio, uma vez que a observância da lei precisa ser comum, pública.

Estaríamos com isso concedendo primazia a iuris consensus, em detrimento de utilitatis communio? Não, pois tanto quanto o iuris consensus implica a utilitatis communio, esta implica aquele. Mais precisamente, iuris consensus e utilitatis communio são indissociáveis, porque se o homem é particula da Razão universal, e se a vera lex é a recta ratio, então a associação por "utilidade comum" é perfeitamente racional e justa: estabelecida pela justeza do homem com a natureza, guarda o ius naturale.

Cícero, assim, teria expressado certa redundância na definição de populus? Seja qual fosse, expressar uma única das duas condições articuladas no plano linguístico pela conjunção et teria sido suficiente para defini-lo? Essas duas condições seriam redutíveis uma à outra? Não, pelo menos por duas razões. Em primeiro lugar, porque, a partir da leitura de De re publica, III, podemos compreender ambas as condições implícitas uma na outra, o que, todavia, não quer dizer que uma condição seja redutível à outra: uma condição encontrar-se implícita na outra deve ser compreendido como implicação recíproca e complementar estabelecida entre elas, não como redutibilidade. Em segundo

27. Idem, p. 105. 
lugar, porque antes do livro III não há notícias da implicação recíproca das condições da definição; com efeito, mediante os livros I e II sequer sabemos se os conceitos de direito (ius) e justiça (iustitia) têm fundamento naturalista e intelectualista (lex naturale $=$ recta ratio). Por consequência, a utilitatis communio, por um lado, precisa estar presente na definição de populus, precisamente para demarcar que não se trata de iuris consensus estabelecido por via de coerção ou convenção ${ }^{28}$, por exemplo. Por outro lado, o iuris consensus também precisa estar expresso, porque apenas a utilitatis communio não diz se o útil deve coincidir com o direito, nem se o útil e o honesto guardam identidade, nem se o útil é regulado pelo direito em direção a um fim. Não por acaso, todas as constituições de cidade marcadas por leis tirânicas e por vantagens privadas são corrompidas.

Além do mais, a disposição das duas condições na definição ainda nos indica o itinerário argumentativo da obra De re publica, pelo menos até o livro III. Afinal, após o empreendimento da definição (livro I), segue-se visão histórica de frágeis iuris consensus e falsas utilitatis communiones, o que permite conceber Roma com traços do optimus status civitatis (livro II), e, disso, a discussão sobre o fundamento naturalismo e intelectualismo da lei é encaminhada (livro III). Assim, a estrutura da definição de populus delineia pelo menos a estrutura inicial de De re publica, de sorte que a desatenção a cada uma das condições e à conjunção et, que lhes relaciona as expressões, significa recusa de compreensão da própria definição e da obra. Nesse sentido, "a definição desempenha função completamente específica no diálogo: a de operar como critério de legitimidade, [...] para fornecer os motivos de distinguir constituições/politeiail organizações/'regimes' [...] legítimos de ilegítimos" ${ }^{\prime \prime 29}$.

28. Ainda que a integridade da obra De re publica tenha se perdido, sustentamos a hipótese interpretativa de conjunto da obra até o livro III, porque se a discussão sobre o direito por coerção ou convenção tivesse tido solução nos livros I e II, ela não teria emergência no III como principal problema de discussão.

29. "[...] the definition bas a quite specific function in the dialogue, namely to operate as a criterion of legitimacy [... to furnish the grounds of a distinction between constitutions/ politeiai/set-ups/'regimes' [...] that are legitimate and those that are not." SCHOFIELD, M. Cicero's Definition of Res Publica. In: POWELL, J. G. F. Cicero the philosopher - Twelve papers. Oxford: Clarendon Press, 1995, p. 64. 
Finalmente, o sentido da conjunção et na definição ciceroniana de populus é o de adição e expressa dois elementos constitutivos da cidade fundados em reciprocidade e simultaneidade. Nenhuma das duas condições pode ser cumprida solitariamente, em anterioridade lógica e/ou temporal em relação à outra, o que evidencia que nenhuma pode desempenhar a função de condição suficiente: ambas são igualmente necessárias, condições sem as quais a referência de populus não pode existir. Tal compreensão, todavia, somente é descoberta de forma inequívoca em De re publica, III, onde se dá a discussão sobre a justiça e o direito a partir da contiguidade estoica entre "divindade", "natureza", "razão" e "cidade". Aí também é esclarecido que o caráter comum do que é útil (utilitatis communio) contém algo de natural e divino. Afinal, o obscurecimento e o rebaixamento à categoria de vício de toda utilidade exclusivamente particular já significam, por si sós, justeza do homem com a natureza, cumprimento do ius naturale sob a forma do iuris consensus.

\section{Referências bibliográficas:}

AUGUSTINUS. De civitate dei. Corpus Christianorum Series Latina XLVII (Libri I-X) e XLVIII (Libri XI-XXII). Turnhout: Brepols, 1955.

CICERO. De natura deorum. Stuttgart: Bibliotheca scriptorum Graecorum et Romanorum Teubneriana, 1961.

De officiis. Leipzig: Bibliotheca scriptorum Graecorum et Romanorum Teubneriana, 1963.

De re publica. Leipzig: Bibliotheca scriptorum Graecorum et Romanorum Teubneriana, 1964.

De legibus. Trad. Keyes, C. W. (edição bilíngue). Cambridge, Massachusetts, London: Harvard University Press, 1988.

ARENDT, H. Entre o passado e o futuro. Trad. Barbosa, M. W. São Paulo: Perspectiva, 2003.

BARROS, A. R. O estoicismo moral de Cícero: virtudes e deveres para homens comuns. In: Phrónesis, Vol. 8, N. 2 Julho, 2006.

GRAMMATICO, G. El príncipe como espejo del dios en La República de Cicerón. In: ARBEA, A.; GRAMMATICO, G.; CAJAS, H. H. Cicerón, un alma ardiente. Santiago: Editorial Universitaria, 1994.

GRIMAL, P. Cicéron. France: Librairie Arthème Fayard, 1986.

REVELLI, M. Cicerone, Sant'Agostino, San tommaso. Torino: G. Giappichelli Editore, 1989. 
Luiz Marcos da Silva Filho

SCHOFIELD, M. Cicero's Definition of Res Publica. In: POWELL, J. G.

F. Cicero the philosopher - Twelve papers. Oxford: Clarendon Press, 1995.

VEYNE, P. Humanitas: romanos e não romanos. In: GIARDINA, A. O bomem romano. Lisboa: Presença, 1992.

WATSON, G. The Natural Law and Stoicism. In: LONG, A. A. Problems in Stoicism. London: The Athlone Press, 1996.

WOOD, N. Cicero's Social and Political Thought. Oxford: University of California Press, 1988. 


\title{
APRESENTAÇÃO
}

\section{Toda crítica da metafísica é metafísica}

\author{
Fernando Costa Mattos \\ Professor de filosofia na UFABC e pesquisador do CEBRAP
}

"Só se pode lutar contra a metafísica com outra
metafísica." - WOLFGANG STEGMÜLLER

Ao traduzir e publicar esse texto de Volker Gerhardt, escrito há vinte e cinco anos, eu gostaria de chamar novamente a atenção para a polêmica em torno da metafísica que se havia estabelecido na época entre Dieter Henrich e Jürgen Habermas, culminando na publicação, por este último, de seu livro Pensamento pós-metafísico (1988). ${ }^{2}$ Em seu número XIV, estes mesmos Cadernos publicaram a minha tradução do principal texto de Dieter Henrich nesse episódio - as suas "Doze teses contra Jürgen Habermas", de 1985 - e um artigo, de minha autoria, comentando a disputa acerca da morte ou sobrevivência (ou renascimento, se preferirem) da metafísica. ${ }^{3}$ Tendo em vista a recente publicação por Habermas do segundo volume de Pensamento pós-metafísico (2012), ${ }^{4}$ pode-se dizer que a questão continua não apenas viva, mas bastante atual.

Volker Gerhardt (1944-) foi orientando de Friedrich Kaulbach (1912-92) e, a exemplo do mestre, concentrou seus estudos principal-

1. Frase citada por Gerhardt no texto aqui traduzido: "A metafísica e sua crítica", p. 116.

2. HABERMAS, J. Nachmetapbysisches Denken. Franfurt a.M.: Suhrkamp, 1988. Em português: Habermas, J. Pensamento pós-metafísico. Rio de Janeiro: Tempo Brasileiro, 1990.

3. MATTOS, F.C. "Intersubjetivismo versus subjetivismo? Algumas considerações sobre a controvérsia Habermas-Henrich a partir das 'Doze teses contra Jürgen Habermas'"'. In: Cadernos de Filosofia Alemã, n. 14, jul.-dez.2009.

4. HABERMAS, J. Nacbmetaphysisches Denken, Bd.II. Frankfurt a.M.: Suhrkamp, 2012. 


\section{Fernando Costa Mattos}

mente nas obras de Immanuel Kant e Friedrich Nietzsche, sobre as quais publicou diversos livros. ${ }^{5}$ A partir dessa base, e em razoável sintonia com a filosofia perspectivista de Kaulbach, ${ }^{6}$ Gerhardt sempre teve no indivíduo um dos pontos fortes de suas preocupações teóricas: em Individualität. Das Element der Welt (2000), ele defende a polêmica tese de que a noção de indivíduo entre os antigos gregos não é tão distinta daquela dos modernos, podendo-se afirmar que o indivíduo e sua autocompreensão sempre constituíram um objeto fundamental da filosofia. Deste ponto de vista, conceitos como os de autonomia e liberdade individual fornecem a base necessária para a moral e a política, âmbitos em que Volker Gerhardt tem tido destacada atuação seja enquanto teórico, seja enquanto participante da vida política (como intelectual do FDP, o partido liberal da Alemanha).

Do ponto de vista teórico, Gerhardt propõe um "liberalismo existencial" como forma de conciliar a dimensão político-jurídica, em que o respeito às liberdades individuais pauta a atuação do Estado e as relações interpessoais, com a dimensão ético-reflexiva individual, em que cada ser humano, lutando por sua autorrealização, pode constituir um caso exemplar para seus semelhantes. ${ }^{7}$ A seu ver, essa conciliação é um dos grandes objetivos da filosofia desde os antigos, e segue a ser um grande desafio para os modernos: conhecido por relativizar as grandes rupturas que se costuma estabelecer entre as diferentes épocas históricas, Gerhardt bebe em fontes as mais diversas para reconstruir tal problemática e, consciente das novas questões aportadas pelo presente (vide suas reflexões a respeito da biotecnologia), ${ }_{1}^{8}$ indicar possíveis soluções.

5. Sobre Nietzsche: Patbos und Distanz: Studien zur Pbilosopbie Friedrich Nietzsches. Stuttgart: Reclam, 1988; Vom Willen zur Macbt. Antbropologie und Metaphysik der Macbt am exemplarischen Fall Friedrich Nietzsches. Berlin, New York: W.de Gruyter, 1996; Friedrich Nietzsche. München: Beck, 2006. Sobre Kant: Immanuel Kants Entwurf 'Zum ewigen Frieden'. Eine Theorie der Politik. Darmstadt: Wissenschaftliche Buchgesellschaft, 1999; Immanuel Kant: Vernunft und Leben. Stuttgart: Reclam, 2002.

6. Cf. KAULBACH, F. Philosopbie des Perspektivismus. Tübingen: J.C.B.Mohr, 1990.

7. Cf. GERHARDT, V. Existentieller Liberalismus: Beiträge zur Politischen Pbilosopbie und zum politischen Zeitgescheben. Berlin: Duncker \& Humblot, 2009.

8. Cf. GERHARDT, V. Die angeborene Würde des Menschen: Aufsätze zur Biopolitik. Berlin: Parerga, 2003. 
Isso revela, sem dúvida, uma visão até certo ponto continuísta da história da filosofia, no sentido de que as "velhas" questões continuam vivas, e as "novas" têm raízes em suas antepassadas. Nada mais descabido, portanto, do que decretar a morte da "metafísica", como se todo o leque de questões normalmente associadas a esse nome tivesse seu sentido estritamente vinculado às preocupações de um certo período histórico, e se tornasse obsoleto em função das "nossas" mais "autênticas" preocupações. Como é esta, porém, a posição de muitos autores da cena contemporânea, compreende-se que Volker Gerhardt não tenha demorado a tomar partido de Dieter Henrich na polêmica que este travava com Jürgen Habermas a esse respeito nos anos 1980: era preciso salvar a metafísica - ou a própria filosofia, no entender de Henrich e Gerhardt - dos ataques contra ela desferidos por "sociólogos" como Habermas.

Nos artigos que escreveu à época, com efeito, Dieter Henrich procurava vincular a decretação de morte da metafísica - decretação que já se tornou, ela mesma, um clássico da filosofia ${ }^{9}$ à prevalência de uma atitude cientificista, materialista ou, para usar um termo mais up-to-date, "naturalista": ${ }^{10}$ para descartar as próprias questões metafísicas, é preciso aceitar, indo contra a advertência kantiana, que o mundo "tal como nós o vemos" (isto é, o mundo fenomênico) é tudo, nada havendo para além (ou aquém) dele - uma afirmação cujo teor metafísico e dogmático já era apontado pelo próprio Kant. Ora! Qualquer ciência - seja ela natural ou humana - que vire as costas à filosofia e, circunscrita ao seu ângulo específico de análise do real, afirme prescindir de uma reflexão crítica sobre os limites do conhecimento (objeto próprio a toda "metafísica futura que queira apresentar-se como ciência", ${ }^{11}$ para

9. Basta lembrar de Hume, que, no século XVIII, escrevia: "Se nos cai nas mãos um volume, por exemplo, de teologia ou de metafísica escolástica, perguntamo-nos: Contém alguma argumentação abstrata sobre a quantidade ou os números? Não. Contém alguma argumentação experimental sobre questões de fato e existência? Não. Então, que seja jogado ao fogo, pois contém apenas sofismas e ilusões." HUME, D. Investigação acerca do entendimento bumano. Trad. Anoar Aiex. Brasil: Acropolis (e-book), 2006.

10. Cf. HENRICH, D. "O que é metafísica? - O que é modernidade? Doze teses contra Jürgen Habermas." In: Cadernos de Filosofia Alemã, n. 14, jul.-dez.2009, p. 94 e ss.

11. Referimo-nos, evidentemente, ao título da obra: Kant, I. Prolegômenos a toda metafísica futura que queira apresentar-se como ciência. Trad. Artur Morão. Lisboa: Edições 70, 2008. 


\section{Fernando Costa Mattos}

lembrar a célebre formulação de Kant) torna-se dogmática e, pelo excesso de pretensão, metafísica (no sentido pré-kantiano do termo).

É evidente que a posição de Habermas não se deixa ilustrar por uma caricatura tão rasteira, mas o fato de ele posicionar-se contra qualquer abordagem metafísica implica, no limite - e talvez à revelia de suas próprias intenções -, dar razão ao cientista acrítico que se recusa a problematizar seus pressupostos. A crença na ciência, dizia Nietzsche, é tão metafísica quanto a crença em Deus ${ }_{i}{ }^{12}$ e a pretensão de refutar a metafísica é tão metafísica quanto a pretensão de fundamentá-la objetivamente - algo que desde Kant não se pretende. "A metafísica e a crítica da metafísica se tornam uma unidade simbiótica", diz Gerhardt, comentando "as contradições da filosofia moderna em relação à metafísica": ${ }^{13}$ é somente Kant, abandonando as pretensões de conhecimento da metafísica clássica, mas abstendo-se de jogar fora a criança junto com a água suja (como queria Hume), quem instiuirá um modo sensato - leia-se crítico - de lidar com essas contradições:

(...) o significado paradigmático da "revolução copernicana" de 1781 está no fato de Kant não abandonar essas ideias céticas e, apesar disso, defender a possibilidade de uma metafísica científica. Ele conhece os limites estreitos do saber humano e, consciente da circunstância de que o ser humano tende a ultrapassar todas as fronteiras, procura determinar esses limites. A metafísica se transforma em uma ciência dos limites no sentido próprio da palavra: uma ciência que obriga o sujeito humano ao autocontrole. ${ }^{14}$

Entendida como essa "ciência dos limites", que "obriga o sujeito humano ao autocontrole", a metafísica se distancia sobremaneira da caricatura em que Habermas costuma apresentá-la: ela não tem como características determinantes o "pensamento de identidade", o "idealismo", a pretensão de ser uma "prima philosophia" ou o "conceito forte de teoria" - características que, segundo propõe Habermas em sua última resposta a Henrich, seriam essenciais à metafísica. ${ }^{15}$ Trata-se antes de um reconhecimento da finitude humana como delimitadora das nossas

12. Cf. NIETZSCHE, F. A gaia ciência. Trad. Paulo César de Souza. São Paulo: Cia. das Letras, 2003, aforismo 344.

13. "A metafísica e sua crítica", p. 110.

14. "A metafísica e sua crítica", pp. 111-112.

15. Cf. HABERMAS, J. Pensamento pós-metafísico, pp. 39-42. 
possibilidades cognitivas e morais: quer nos inclinemos mais a uma compreensão subjetivista ("monológica", diria Habermas) do humano, quer a uma intersubjetivista (ou "comunicativa"), há sempre um polo a que podemos denominar "nosso" - um "foco perspectivador", digamos, a partir do qual se constituem os nossos discursos interpretativos da realidade - e, em contraposição a ele, o polo do "objeto" (Gegen-stand, em alemão) ou "mundo" (que só "conhecemos" enquanto intérpretes).

Desse ponto de vista, o tal "falibilismo", que Habermas aponta como característica essencial do pensamento pós-metafísico, já estaria contido - ao menos em germe - na posição crítica kantiana, após a qual qualquer discurso sobre "o ser enquanto tal" é tão hipotético quanto a mais fantasiosa narrativa mítica de nossa origem. De certo modo, Habermas tem plena consciência disso, mas a insistência em tratar a virada linguística como uma mudança de paradigma tão importante quanto a virada subjetivista - como se passar do "sujeito" à "linguagem" implicasse sair de algum modo do nosso ponto de vista - o leva a subestimar a contemporaneidade de Kant e, talvez, a superestimar a objetividade e a novidade de sua própria teoria do humano (interpretado como "agir comunicativo"). Se esta visa, com efeito, oferecer uma contribuição para a "autocompreensão" do ser humano ou, que seja, de certas sociedades humanas em seu todo, seria preciso reconhecer, minimamente que fosse, o seu pertencimento à tradição filosófica:

Se não é mais permitida nenhuma interpretação da natureza e da história, e a pergunta pela vida boa se tornou sem sentido, estamos aparentemente tão libertos da metafísica quanto da filosofia - pressupondo-se que esse abandono não esteja fundado em um argumento universal. Mas é exatamente isso que Habermas faz, e, muito consequentemente, situa nessa fundamentação a finalidade da filosofia ainda remanescente. Nesta determinação de uma finalidade, porém, retorna em toda a sua abrangência a tarefa clássica da filosofia. A filosofia, diz-se aí, consiste a partir de agora em uma "autoentendimento" sobre o caráter do saber moderno, e teria como tarefa específica perguntar-se pela unidade da razão na teoria e na prática. Não se nota aqui a referida limitação do horizonte temáti$\mathrm{CO}_{i}$ nem mesmo a terminologia é particularmente nova. Pois quando é que a filosofia foi algo diverso de uma autoentendimento do bomem sobre aquilo que ele sabe? Não podem as questões da filosofia ser todas reunidas sob a questão da unidade da razão ${ }^{16}$

16. "A metafísica e sua crítica", p. 126. 


\section{Fernando Costa Mattos}

As questões colocadas por Volker Gerhardt, com as quais eu gostaria de encerrar esta brevíssima apresentação, dizem respeito à obsessão de Habermas em "superar", em deixar para trás, não somente a metafísica enquanto tal (?!), mas muito do que caracterizava - e, talvez, caracteriza ainda - a própria filosofia. Trata-se de uma obsessão, aliás, que está longe de ser uma exclusividade de Habermas: como ele próprio costuma apontar, é constitutivo do "discurso da modernidade", a partir de sua aguda consciência da temporalidade, instituir por si mesmo os seus padrões de legitimação - desconsiderando a força normativa da tradição. A moda do "pós-" (pós-metafísico, pós-tradicional, pós-moderno etc) tem pelo menos 200 anos, e o que Gerhardt nos propõe a repensar, fazendo coro com Dieter Henrich, é justamente se não está na hora de abandonar essa moda e, aceitando a recomendação de modéstia do próprio Habermas (tão compatível com o espírito do kantismo), verificar se as vozes da tradição filosófica não têm muito a nos ensinar em termos de nossa própria autocompreensão - nem por isso menos voltada ao presente e ao futuro. 


\title{
A Metafísica e sua Crítica. \\ Sobre o debate entre Jürgen Habermas e Dieter Henrich em torno da metafísica'
}

\author{
Volker Gerhardt \\ Professor de filosofia na Humboldt Universität zu Berlin, Alemanha
}

\section{A suspeita contra a metafísica}

Também a filosofia tem suas modas, mas elas parecem, frequentemente, tão atemporais quanto seus grandes temas. Um exemplo é dado pela atitude, já atual há séculos, de enfim acabar com a metafísica. Embora o fim continue sendo aguardado, não se cansam de despedir-se dela em definitivo. O gesto se tornou óbvio há muito e, como acusação de metafísica contra os outros, virou um dos meios preferidos de autopromoção. Isto é facilmente compreensível, pois é uma forma de alguém contrapor-se a uma tradição realmente grandiosa - tão grandiosa quanto a avaliação que se faz da própria posição. Quem o faz parece estar em sintonia com a época e, com isso, mostra-se tão inabalável quanto aqueles primeiros espíritos livres que arriscavam a profissão e a vida na defesa de uma separação entre filosofia e teologia. Esse efeito só pode ser esperado, evidentemente, de um público que não sabe justamente o quanto a posição da metafísica mudou com o afastamento da filosofia em relação à teologia. Como iluminista só pode valer, aqui, quem não se comporta como tal - um autêntico caso da chamada dialética do iluminismo (Aufklärung).

No começo, enquanto a relação entre metafísica e ciência ainda não havia se tornado um problema, a suspeita dirigida contra a metafísica podia nascer de boa fé. Mais tarde, depois de Kant, dedicaram-se consideráveis esforços ideológicos e metodológicos - como o mostram os exemplos de Comte e Marx, Nietzsche e Dilthey - para

1. Título original: "Metaphysik und ihre Kritik. Zur Metaphysikdebatte zwischen Jürgen Habermas und Dieter Henrich". Publicado em Zeitschrift für philosopbische Forschung, vol.42, n. 1, jan.-mar. 1988. 
concretizar a rejeição da metafísica de maneira subjetivamente persuasiva. É sabido, contudo, que essas tentativas não se caracterizaram pelo espírito de sobriedade e imparcialidade que se costuma supor numa crítica da metafísica. Quem, no entanto, depois de Carnap e de tudo o que aprendemos a partir de Heidegger, opera ainda com uma mera acusação de metafísica, precisa primeiro escurecer a cena, para então poder lançar sua luz.

Assim procedeu Jürgen Habermas quando, em artigo na revista Merkur, ${ }^{2}$ colocou no mesmo saco, sob suspeita de metafísica, não apenas os defensores daquilo que chamou de "neoaristotelismo hermeneuticamente falido", mas também os filósofos que reconhecem na questão da autoconsciência um problema independente. "À sombra do espírito da época", esses obscurantistas por ele descobertos não se satisfazem em conjurar a "transformação" política ou, como "defensores intelectuais da Constituição", fornecer "dossiês" à chancelaria do Estado; eles fazem ainda metafísica - "não menos pretensiosos, ao fim das contas, do que Peter Handke, que se propõe entrementes a devolver à poesia a qualidade do canto profético, da visionariedade". ${ }^{3}$ Uma vez que se tenha caracterizado desse modo a metafísica e os metafísicos, não é difícil posicionar-se contra eles e, em nome da ciência, apresentar-se como advogado de um "mundo desencantado e desmitologizado".

Infelizmente, não é nova, na escola que Habermas representa, a estratégia de autopromover-se publicamente às custas de outros. Às motivações que animavam os fundadores da Escola de Frankfurt pertencia uma profunda necessidade de inimigos, e esta não pode ser compreendida como mera forma de reagir à perseguição política. Que se leiam as amargas observações de Hannah Arendt sobre os fundadores da teoria crítica. ${ }^{4}$ Seria melhor, para o discurso filosófico na República

2. HABERMAS, J.Rückkehr zur Metaphysik - eine Tendenz in der deutschen Philosophie? In: Merkur, 39 (1985), pp. 898-905. * Esse texto seria publicado como apêndice ao livro Nacbmetapbysisches Denken, de 1988. Cf. HABERMAS, J. Pensamento pós-metafísico. Rio de Janeiro: Tempo Brasileiro, 2002. (N. do T.)

3. Idem, pp. 898, 900 e 903. Em vista do "patriotismo constitucional", a que Habermas deu expressão recentemente, talvez não seja pouco importante a indicação de que ele liga o conceito de "defensor intelectual da constituição" a uma forte acusação moral.

4. ARENDT, H. e JASPERS, K. Briefwechsel 1926-1969. München/Zürich, 1985, p. 670 . 
Federal da Alemanha, se o mais importante discípulo de Horkheimer e Adorno não se libertasse somente - como de fato pretende - da parcialidade histórico-filosófica de seus mestres, mas também da sua parcialidade afetiva. Aquilo que neles é - quando muito - subjetivamente compreensível torna-se em Habermas um mero ritual.

Deve-se acrescentar, decerto, que até hoje nenhuma escola filosófica conseguiu escapar de uma autoafirmação pública por meio do contraste. É praticamente inevitável recorrer a elementos retóricos quando se busca esclarecer opiniões e argumentos - uma certa polêmica é sempre uma expressão de vitalidade de uma construção teórica científica. À medida que não se firam regras de fairness, não se abandone a base argumentativa e não se exija mais do oponente do que de si próprio, a polêmica não há de ser prejudicial. E não se deve jamais fugir dela.

Mas em Habermas a polêmica traz ainda uma outra dificuldade: não é fácil perceber a ligação dela com a teoria que sai para o ataque. Onde a polêmica introduz momentos de suspeita como se fossem argumentos, o agir instrumental e o agir comunicativo ficam de tal modo encobertos que se pode chegar a duvidar do sentido dessa distinção conceitual. Ou se confia na força discursiva do argumento, e a polêmica então só atrapalha - independentemente de ela apresentar-se como ato estratégico ou autoencenação expressiva; ou se vê o outro principalmente como adversário, e então a pretensão de consenso não passa de um cálculo em uma relação que é, na melhor das hipóteses, cognitivo-estratégica. É claro que não precisamos, necessariamente, entender essa complexidade do agir orientado pelo sucesso e pelo entendimento como objeção à sua diferenciação: Habermas só pretende reconhecer nesses atos "tipos puros". ${ }^{5} \mathrm{Se}$, no entanto, esses tipos puros da interação linguisticamente mediada aparecem assim misturados em seu próprio defensor, isto constitui uma boa razão para colocar uma interrogação por trás da diferenciação: até que ponto se pode considerar válido esse fundamento verdadeiramente neoaristotélico - baseado na "poiesis" e na "práxis" - da teoria da ação comunicativa?

O quanto Habermas entende da estratégia do agir comunicativo é algo que foi colocado à prova, nesse meio tempo, em sua réplica à

5. HABERMAS, J. Theorie des kommunikativen Handelns. Frankfurt am Main: Suhrkamp, 1981, vol. 1, p. 439. 
resposta que Dieter Henrich ${ }^{6}$ he havia dado na polêmica. ${ }^{7} \mathrm{O}$ seu ataque genérico à metafísica contemporânea, apresentado no outono de 1985, já não pode ser visto, no começo de 1987, como uma "resenha" que o adversário deveria receber "generosamente", por ocasião de uma "discussão metacrítica". ${ }^{8}$ Quem não conhece a ocasião (ou já não se lembra bem dela) tende a acreditar que Henrich teria jogado a primeira pedra e, assim, forçado Habermas a tomar parte na discussão metateórica. O seu próprio artigo, que suscitou o debate, é deixado de $l_{a d o}$ já não se fala da pesada artilharia pública que, sem esclarecer nenhuma dúvida, ele havia dirigido contra a metafísica. Em vez disso, diz-se que o oponente respondeu à incidental questão "o que é metafísica?" com um "esboço poderoso" - ao qual ele, Habermas, "não tem condições de reagir do mesmo modo". A modéstia com que Habermas se diz somente capaz de um mero "pré-entendimento" acerca da atividade filosófica seria surpreendente se não se tratasse do mesmo autor que, havia pouco mais de um ano, se tinha expressado sobre o mesmo tema no estilo de um panfletista político.

Mas a mudança no tom pode ser um sinal! Habermas toma distância de sua própria polêmica. A suspeita não é mais disseminada. Pelo contrário: na medida em que ele próprio se esforça pelo entendimento, fica pressuposto que a questão da metafísica não é afastada nem por fatos evidentes, nem por um desenvolvimento histórico amplamente reconhecido; a posição que se toma em relação à metafísica já não parece ser um sinal inequívoco de progresso político e científico. Mesmo a insinuação maliciosa de que Henrich seria um filósofo conservador se vê relativizada, ainda que de modo sutil: o colega é agora enfaticamente elogiado por não pertencer à "grande

6. HENRICH, D. Was ist Metaphysik, was Moderne? Zwölf Thesen gegen Jürgen Habermas. In: Merkur, 40 (1986), p. 405-508. * Conferir também o livro que deu ocasião à crítica de Habermas: HENRICH, D. Flucbtlinien. Frankfurt am Main, 1982. O artigo a que Gerhardt se refere foi por nós traduzido para o português: HENRICH, D. O que é metafísica? O que é modernidade? Doze teses contra Jürgen Habermas. In: Cadernos de Filosofia Alemã, n. XIV, jul.-dez.2009. (N. do T.)

7. HABERMAS, J. Metaphysik nach Kant. In: CRAMER, H. et alli. Theorie der Subjektivität. Festschrift für D. Henrich. Frankfurt am Main, 1987, p. 425-443. Esse texto seria publicado no livro Nachmetapbysisches Denken, de 1988, como capítulo 2 .

8. Idem, p. 425. 
aliança" contra as ideias da liberdade burguesa. Depois desse desencargo, já não parece tão ruim tê-lo vinculado à pequena coalizão em Bonn. Isso não chega a ser uma retratação, mas é talvez uma declaração de inocência, é, de qualquer modo, uma diferenciação e, nessa medida, também uma transição para um diálogo racional.

Habermas busca agora, portanto, uma explicação mais objetiva da questão. Sobre a palavra que lhe deu ocasião para o primeiro golpe ele já não quer discutir. A "disputa terminológica", diz ele com precisão, "não nos leva adiante na questão". ${ }^{9}$ Logo, a suspeita que se levanta somente contra a palavra é inócua. A mera indicação de que aqui ou ali se faz "metafísica" desvia do tema. Se Habermas tivesse chegado antes a essa conclusão, ele também teria entendido antes a questão. Mas ele fala por si quando diz que agora está tentando, e que pretende estimular a discussão com uma contribuição clara e aberta.

$\mathrm{Na}$ expectativa de que o debate prossiga nos termos propostos por Dieter Henrich, farei as seguintes considerações sobre a conexão entre a metafísica e sua crítica na modernidade (2). A maior ênfase recairá sobre o conceito crítico de metafísica formulado por Kant, ao qual também Henrich e Habermas se referem. Em seguida (3), tentarei mostrar que o próprio Habermas, com a ampla pretensão de conhecimento e ação de sua teoria crítica, permanece na problemática clássica da metafísica - mas tem, quanto a isso, boas razões para crer que a mera suspeita contra a metafísica não permanecerá em voga.

\section{Modernidade e metafísica}

É moderno aquilo que está em sintonia com a sua época. Nesse sentido, a modernidade é sempre insuperável, mas é a todo instante superada. À luz dessa simples observação, tanto os teóricos da modernidade como os da pós-modernidade poderiam ter-se poupado de esforços conceituais desnecessários. Também do ponto de vista histórico há um critério esclarecedor, que determina já o primeiro uso da palavra na querela dos anciens e modernes: é "moderno" aquilo que já não se considera "antigo"; aquilo que delimita a si próprio como a modernidade. $\mathrm{O}$ que é decisivo é a autocaracterização do presente como "novo tempo". Com a plena sensação de possuir novos conceitos e propósitos, imaginamos estar no limiar de uma outra época e, embora

9. $\quad$ Idem, p. 429. 
julguemos interessante a visão de mundo da época antiga, a tomamos como algo meramente histórico. Tem-se aí a expectativa de uma transformação histórica no plano dos princípios, uma transformação que é construída mesmo ali onde se tem consciência do inexorável destino humano.

Não seria difícil oferecer outras definições da modernidade, já que não há nada de novo nisso que se apresenta como autoimagem da época. É claro que são novas as circunstâncias em que ainda hoje damos continuidade à evolução dos novos tempos: o aperfeiçoamento recente das teorias matemáticas e das técnicas manuais; as sucessivas e rapidamente substituíveis inovações técnicas, com suas abrangentes consequências econômicas e sociais; a neutralização política da tensão entre as diferentes crenças, realizável apenas com meios jurídicos soberanos; e, por fim, a contínua e inevitável correção das visões de mundo sob a influência dos conhecimentos das ciências naturais. Em parte alguma surge algo inteiramente novo. Na continuidade histórica há apenas uma série de pequenas e dispersas quebras. A modernidade surge como um resultado daquilo que Benjamin Nelson chama de "distribuições de peso cambiantes". ${ }^{10}$

A tradição do pensamento ocidental confia naquilo que, sob tais circunstâncias cambiantes, articula-se como "sujeito moderno". Pois, com a sua pretensão aparentemente revolucionária de autossuficiência e independência, esse sujeito insiste sobretudo no uso da própria razão. Os autores da antiguidade, porém, já definiam essa pretensão como um fim supremo. Sob as circunstâncias cambiáveis o sujeito é certamente exigido de maneira mais intensa - daí a sua pretensão parecer mais radical e arriscada. As mudanças técnicas, sociais e científicas da vida nos séculos XVI e XVII criaram um clima em que o sujeito teve de afirmar-se de maneira agressiva. A autoconsciência se vê pressionada e ameaçada - mas vê a perigosa situação como um desafio ao qual só pode sobreviver se fortalecer a sua própria pretensão. Ela reage por meio de um aumento da autoafirmação. $\mathrm{O}$ ataque autoconsciente nasce de uma posição defensiva, mas permanece ligado às suas condições iniciais.

Em conexão com as novas técnicas, é sobretudo a pretensão humana de dispor das coisas que aparece com mais força e consequências. O âmbito de ação é ampliado. Ao mesmo tempo, o modelo

10. NELSON, B. Der Ursprung der Moderne. Frankfurt am Main, 1977, p. 140 e ss. 
causal de interpretação da natureza chama a atenção para o quanto o próprio sujeito se controla e determina quando age de maneira planejada. Mas seria um erro acreditar que o sujeito moderno se livra de todas as amarras. Ele segue a acreditar na função mediadora da natureza e da sociedade, e também não renuncia a Deus. A recomendação de Platão - sempre usar primeiro a própria razão, e somente então voltar-se aos deuses - é levada tão a sério que, muitas vezes, esse sujeito parece já não ter de rezar para ser religioso.

Moderna é sobretudo a autoimagem do ser humano autoconsciente, que se compreende como aquela parte da natureza que - apesar de toda dependência - tem de cuidar de si mesma. A autoconservação se torna um princípio fundamental do modo como o ser humano conduz sua vida. Não se trata, contudo, de um mero princípio de sobrevivência, mas, em geral, da conservação e desenvolvimento da vontade dirigida pela razão e, portanto, do asseguramento de uma existência humana. A autoconservação, enquanto princípio de um sujeito que quer agir segundo suas próprias representações e por sua própria responsabilidade, é também, diga-se de passagem, a origem de expectativas normativas.

Um indício da conexão que afirmamos entre aquilo que se autodenomina novo e a velha tradição da razão é dado pela circunstância de que a modernidade não conseguiu libertar-se da metafísica. Sabidamente, "metafísica" é o nome que se tornaria usual para, posteriormente, designar aquela ciência que em Aristóteles também se chamava "filosofia primeira", "sabedoria" ou mesmo "teologia". Nesse contexto, ela serve para designar a tarefa central da filosofia tal como ela é compreendida desde Platão. A metafísica é, portanto, o saber que se busca acerca dos primeiros princípios e dos fins mais elevados do ser. Evidentemente, essa definição é passível de questionamento. No que diz respeito à sua origem, porém, não é difícil reconhecer na metafísica o acabamento da filosofia ${ }_{i}$ é ela que preenche o pano de fundo a partir do qual se pode compreender as questões filosóficas singulares. Na visão de hoje, ela é a tentativa extrema de medir as realizações da razão humana. Ela não pretende menos do que colocar sob conceitos o todo que nos é acessível.

Essa intenção deixa claro que é justamente a metafísica tradicional que deve lançar um desafio à modernidade. Pois, em primeiro lugar, a metafísica constitui, já em sua versão clássica, uma ampliação do pensamento humano, demonstrando de maneira explícita aquilo que 
a modernidade quer superar. Em segundo lugar, os conteúdos da metafísica tradicional representam aquele mundo antigo diante do qual surge o sujeito moderno em sua estilizada autoavaliação Assim, o que se faz é imitar os metafísicos para, justamente assim, superá-los. Podemos desvendar a partir dessa dupla motivação, com efeito, as contradições da filosofia moderna em relação à metafísica. A metafísica e a crítica da metafísica se tornam uma unidade simbiótica.

Os humanistas do século XVI fornecem o prelúdio para a crítica moderna da metafísica. É preciso "ser um Linceu", escreve Erasmo de Rotterdam, "que enxerga o nada através da mais densa escuridão", para saber o que significam os conceitos metafísicos dos escolásticos. ${ }^{11} \mathrm{O}$ escárnio sobre a "especulação fantástica e bruta" dos "obscurantistas"12 metafísicos se difunde com rapidez e logo se torna o instrumento preferido da polêmica reformista. Mas as grandes manifestações do pensamento moderno aparecem sobretudo na forma de sistemas metafísicos. Descartes percorre os novos métodos científicos em sua integralidade, e estimula com isso não apenas em Espinosa e Leibniz, mas também em Hobbes, os verdadeiros pontos altos do pensamento metafísico especulativo - pontos altos que, como permite notar o "Nosce te ipsum" na introdução ao Leviata ${ }_{1}^{13}$ permanecem comprometidos com o ideal socrático do autoconhecimento. A crítica genérica à metafísica, que também se encontra nesses autores, apresenta-se como uma crítica a determinadas suposições e procedimentos metafísicos, mas não deve ser tomada como um julgamento sobre a metafísica como um todo.

Isso vale também para a segunda grande fase da crítica moderna à metafísica, que é levada adiante, de maneira bastante expressiva, pelos empiristas e céticos da era da razão. No entanto, por mais geral que sua crítica pareça, ela só é, na verdade, direcionada contra determinadas posições metafísicas. Enquanto John Locke só consegue ver na metafísica uma técnica para cunhar conceitos vazios, seu admirador D'Alembert não vê nada demais em festejá-lo como o criador de uma nova metafísica, com a qual a filosofia teria conseguido articular-se à

11. Erasmo de Rotterdam. Das Lob der Torheit. In: Werke, vol. 2, p. 133.

12. Cf., quanto a isso, o instrutivo artigo: RENTSCH, T. Metaphysikkritik. In: Historisches Wörterbuch der Pbilosopbie, vol. 5, p. 1279 e ss. Sobre a pré-história desse desenvolvimento, cf. BECKMANN, J. Zur Transformation von Metaphysik durch Kritik. In: Pbilosopbisches Jabrbuch, 92, 1985, p. 291-308.

13. HOBBES, T. Leviathan. Baltimore: Macpherson, 1968, p. 82. 
ciência da natureza de Newton. ${ }^{14}$ Voltaire é conhecido pela afirmação anedótica "vanitas, vanitatum, et metaphysica vanitas" e, no entanto, escreveu um respeitável "Tratado de Metafísica" - no qual ele parte apenas daquilo que a Terra ("este pequeno monte de lama") oferece ao conhecimento, e só pretende avançar até onde seja possível para o ser humano. ${ }^{15}$ De qualquer modo, Voltaire não vê contradição alguma no fato de o Rei da Prússia atribuir-lhe "uma grande revolução no modo de pensar dos seres humanos" e, ao mesmo tempo, alcunhá-lo de metafísico. ${ }^{16}$

A "revolução no modo de pensar" que seria então realizada por Kant também não conduziu, como é bem sabido, a um abandono da metafísica. Os escritos pré-críticos de Kant dão por vezes a impressão, é verdade, de que ele quereria romper o quanto antes com essa "suscetível amante", para a partir de então ater-se àquilo que é útil no solo da experiência - uma consequência que parece inevitável após ele ter decidido consigo mesmo que o conhecimento tem de servir à vida, está ligado às impressões sensíveis (portanto fugidias) e, no que diz respeito à realidade como um todo, erra por princípio - a "tendência ao erro" pertence ao próprio conceito de espírito humano. ${ }^{17}$ Mas o significado paradigmático da "revolução copernicana" de 1781 está no fato de Kant não abandonar essas ideias céticas e, apesar disso, defender a possibilidade de uma metafísica científica. Ele conhece os limites estreitos do saber humano e, consciente da circunstância de que o ser humano tende a ultrapassar todas as fronteiras, procura determinar esses limites. A metafísica se transforma em uma ciência dos limites no sentido próprio da palavra: uma ciência que obriga o sujeito humano ao autocontrole.

A argumentação de Kant segue uma intuição simples: por mais estreito que seja o espaço do conhecimento metafísico, há sempre nele uma pretensão a conceitos que, mesmo quando ultrapassamos os li-

14. D'ALEMBERT, J. Einleitung. In: Enzyklopädie (1751). Hamburg, 1955, p. 155 e ss.

15. VOLTAIRE. Metapbysische Abbandlung (1734). Frankfurt am Main, 1978, pp. 9 e 34.

16. MÖNCH, W. Voltaire und Friedrich der Grösse. Das Drama einer denkwürdigen Freundschaft. Stuttgart/Berlin, 1943, p. 382.

17. KANT, I. Versuch, den Begriff der negativen Grössen in die Weltweisheit einzuführen (1763). In: Akademische Ausgabe (Ak.A.), vol. 2, pp. 202 e 480. 
mites da sensibilidade, nunca abandonamos. Neste caso, os conceitos se tornam evidentemente vazios, mas, criticamente considerados, continuam a ter significado para a ordenação de nosso saber e a orientação de nosso agir. Na medida, pois, em que pensamos e agimos, não conseguimos livrar-nos dos conceitos; e, enquanto não cessarmos de fundar nosso conhecimento do mundo em conceitos, também não conseguiremos livrar-nos da metafísica - pressupondo-se, naturalmente, que continuamos interessados em entender nossa relação com o mundo. A relação com o mundo, no entanto, é sempre também uma relação conosco mesmos. Isto é muito semelhante ao que ocorre com a linguagem: Kant sabe, naturalmente, que alguém fala para tornar-se compreensível aos demais. E ele afirma que precisamos das palavras "não apenas para compreender os outros, mas para tornar-nos compreensíveis a nós mesmos". ${ }^{18}$ Chamar a linguagem de "monológica", portanto, é algo que não ocorreria a ninguém.

O elemento moderno do projeto kantiano pode ser percebido no fato de ele colocar em primeiro plano a pressuposição da autorreferencialidade humana que é fundamental para todo conhecimento e agir. ${ }^{19}$ Embora Kant saiba o quanto deve, justamente em sua crítica da metafísica, ao chamado socrático-platônico para o autoconhecimento, ele aponta com mais ênfase que qualquer pensador antes dele a participação do sujeito em toda objetividade sequer pensável. Isto levou ao equívoco, ainda hoje difundido, de achar que Kant queria tirar o mundo da faculdade transcendental do sujeito como se tirasse um coelho da cartola. Teríamos aí aquela "geração espontânea" da razão ("sem ter sido fecundada pela experiência") ${ }^{20}$ contra a qual Kant se insurge. Ainda que se tenha sempre tentado, a metafísica não pode, à diferença da matemática, produzir tudo através do mero pensamento. Caso se queira impedir que o seu nome continue a ser "difamado", ${ }^{21} \mathrm{a}$ defesa só poderá valer-se de conceitos meramente "pensados". ${ }^{22}$

18. KANT, I. Reflexionen zur Logik, R 3444. In: idem, vol. 16, p. 839.

19. KANT, I. Träume eines Geistersehers. In: idem, vol. 2, p. 368. Cf. ROHS, P. "Prämisse der Selbstdurchsichtigkeit der Vernunft". In: Forum für Philosophie. (org.) Pbilosopbie als Selbsterbellung der Vernunft. Frankfurt am Main, 1987, pp. 363-405, 383 e ss.

20. KANT, I. Kritik der reinen Vernunft. KrV, B 793.

21. KANT, I. Grundlegung zur Metapbysik der Sitten. In: Ak.A., vol. 4, 410.

22. $\mathrm{KrV}, \mathrm{B} 808$. 
Mas essa operação crítica disciplinadora é ela própria parte da metafísica, já definida, na transição para a filosofia crítica, por meio da "função" de determinação dos limites do conhecimento humano: "a função determina o seu valor" ${ }^{23}$ E ele reside em verificar e assegurar as mínimas possibilidades que restam ao ser humano, na medida em que ele se compreenda como ser racional. Não devemos esquecer que a metafísica crítica originou-se em uma doença, em uma "humilhação" da razão. ${ }^{24} \mathrm{~A}$ confiança nas forças críticas da razão está longe de ser um otimismo racional ininterrompido. O ceticismo, a atitude empirista e o ponto de partida na autocompreensão humana são a expressão de uma modéstia que parece recomendável, de fato, frente às aporias da metafísica especulativa.

Essa desilusão com a tradição metafísica também é reflexo do reconhecimento dos sucessos da ciência experimental da natureza. É evidente que Kant se orienta pelo paradigma dessa ciência ao referirse, no âmbito da dialética, a um "experimento da razão pura". ${ }^{25}$ Isso reforça a pretensão moderna, fundada na experiência, no próprio agir e no interesse autoconsciente, a uma metafísica crítica. A filosofia crítica que é movida pelo pathos da empiria e por uma atitude cética nunca recusou o vínculo, pensado em termos concretos, entre sujeito e objeto. E ela também não abandona esse contexto quando demonstra que, em se tratando de uma condição universal do conhecimento ou do agir, nós sempre voltamos a nós mesmos. E Kant compreendeu cedo a razão disso: "através de nossos sentidos só podem revelar-se as relações das coisas, e nós só podemos representar o absoluto ou sujeito a partir de nós. A ideia de substância vem, de fato, da repraesentatione sui ipsus..."26 Neste sentido, o sujeito aparece como o "limite do mundo", tal como Wittgenstein o formularia. Kant, porém, não julgou necessário tirar de cena a circunstância - por nós conhecida - de determinarmos a nós mesmos e ao mundo a partir desse "limite"; afinal, o eu como limite é sempre também uma "fonte" ou "princípio".

Não se pressupõe aí que o eu exista como um fato entre outros fatos; também não se pressupõe, de modo algum, que nós disponhamos de um conceito de nós mesmos livremente definido. O que há é a

23. Reflexionen zur Metapbysik, R 3918. In: Ak.A., vol. 17, p. 343.

24. $\mathrm{KrV}, \mathrm{B} 823$.

25. $\mathrm{KrV}, \mathrm{B}$ XXI.

26. Reflexionen zur Metapbysik, R 3921. In: Ak.A., vol. 17, p. 346. 
percepção de que, para falar, não podemos prescindir do uso daquilo que sempre entendemos por "eu". Caso se conceda agora que, quando o homem se relaciona com o seu mundo numa atitude cognitiva, algo como a "razão" tem de estar em cena, já chegamos com isso ao conceito crítico de metafísica. Kant realiza isso sem as suposições dogmáticas, que são atribuídas a tal conceito, sobre a essência do eu, do mundo e da razão, quando descreve a metafísica como um "autoconhecimento científica e completamente plausível". Para ele, a metafísica é um "sistema de prevenção e autoexame" e, consequentemente, tem na crítica a sua tarefa primordial. ${ }^{27} \mathrm{O}$ ser humano não para de produzir conceitos e teorias de alcance metafísico. A metafísica como ciência pode, portanto, limitar-se basicamente a examinar os conceitos que surgem, afastar o que for neles insustentável e organizar o que for útil.

Uma ideia do quão indispensável se tornou, após anos de investigação e reflexão, o nome "metafísica" para o empreendimento filosófico de Kant, pode ser obtida na carta em que ele comunicava ao aluno e amigo Marcus Herz a conclusão da Crítica da Razão Pura: "esse tipo de investigação permanecerá para sempre importante, pois ela contém a metafísica da metafísica" ${ }^{28}$

Com seu conceito crítico de metafísica, Kant procura unir em um conceito as duas linhas, até então sempre divergentes, da metafísica sistemática e da crítica cética à metafísica. Mas a sua proposta não convenceu os teóricos do século XIX. Uns se incomodaram com as limitações céticas e procuraram voltar às construções absolutas, podendo permanecer numa identificação da filosofia com a metafísica mais forte que a de Kant. Os outros consideraram o conceito crítico insuficientemente crítico, já que baseado na necessidade de conceitos que, por seu turno, só poderiam ter surgido de circunstâncias pré-conceituais da linguagem, da história e da vida. Aos seus olhos, portanto, Kant ainda se deixaria conduzir por uma suposição dogmática; a tentativa de salvar a metafísica por meio da crítica é considerada por eles como definitivamente fracassada. A acreditar em Nietzsche ou Dilthey, a metafísica morreu justamente do remédio que deveria curá-la. Na verdade, contudo, foi o efeito contrário que se produziu pois poucas coisas inspiraram tanto a discussão sobre a metafísica como

27. $\mathrm{KrV}, \mathrm{B} 739$ e B 877; Prolegomena, §§ 40, 52.

28. Brief an Hertz vom 11.5.1781. In: Ak.A., vol. 10, p. 269. 
a veemente doutrina da vontade de poder, de Nietzsche, ou o recurso hermenêutico à vida, de Dilthey. A partir de então, foi somente a mudança de função dos enunciados metafísicos - a "transformação do seu sentido", para falar com Habermas - que ficou mais clara. A suspeita nietzschiana de que a metafísica seria a ciência "que trata dos erros fundamentais do homem como se fossem verdades fundamentais" permanece de pé. ${ }^{29}$

Que se possa reagir de outro modo às aporias da metafísica tradicional é confirmado pelo exemplo de um contemporâneo de Nietzsche e Dilthey, a saber: Peirce. Ele condena a "situação desesperadoramente atrasada" da metafísica de então, e culpa por ela, no essencial, a "casta dos teólogos" entre os filósofos. ${ }^{30}$ Em vez de examinar criticamente as condições do saber, eles teriam utilizado a metafísica para disfarçar a sua fé. Mas Peirce está muito longe de deduzir dessas circunstâncias um veredito contra a metafísica como um todo. Ele antes acusa os filósofos de terem aceitado tanta "metafísica ruim", e se coloca como meta desenvolver uma metafísica boa, isto é, científica. O objetivo desta estaria vinculado aos temas clássicos da ontologia, ao estudo das "condições universais da realidade e dos objetos reais". ${ }^{31}$ Uma das inúmeras questões com que Peirce delimita o horizonte das investigações metafísicas tem se mostrado até hoje produtiva: "o que é propriamente a consciência ou espírito?"32

A crescente esperança num fim definitivo, numa "eutanásia" da metafísica, igualmente forte na virada do século XX, foi motivada, evidentemente, pelos grandes sucessos das ciências positivas. Com relação a isso, há muito ninguém é tão enfático quanto os primeiros positivistas, os marxistas e os monistas. Talvez a metafísica brotasse de uma necessidade ou instinto passageiro, que não se aquietara ainda, mas ao qual seria perfeitamente possível resistir? Não precisamos - era essa a suposição liberal - chegar ao ponto de achar que o homem deva aquietar-se

29. Cf. GERHARDT, V. Die Metaphysik des Werdens. Über ein traditionelles Element in Nietzsches Lehre vom (Willen zur Macht). In: SIMON, J. (org.) Nietzsche und die pbilosopbische Tradition, vol. 1. Würzburg, 1985, p. 9-33. Cf. Gipfel der Internität. In: Nietzsche-Studien, 16 (1987), p. 444-466.

30. PEIRCE, C. Lectures on Scientific Metaphysics. In: Collected Papers of Ch.S. Peirce, vol. 6. Cambridge: Hartshorne/Weiss, 1935, p. 1.

31. Idem, p. 2 .

32. Idem, p. 6 . 


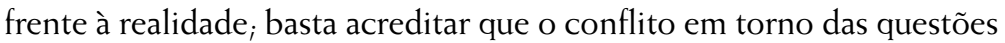
sem respostas possa um dia tornar-se um passatempo para as horas vagas. $O$ vínculo entre a filosofia e o lazer ganharia assim um outro sentido.

Mas o curso da discussão sobre a metafísica no século XX não deixou espaço para essa plausível e razoavelmente simpática expectativa. Pois foram justamente os filósofos que queriam ater-se com toda força ao ideal metodológico das ciências positivas que, em um processo exemplar de progressiva autocorreção, demonstraram - lógica e factualmente - a inviabilidade de uma filosofia inteiramente desprovida de elementos metafísicos. Os teóricos do Círculo de Viena queriam ver-se definitivamente livres do falso problema da metafísica, mas acabaram por fracassar na tentativa de fornecer um critério empírico para diferenciar os verdadeiros problemas dos chamados problemas ilusórios. Com isso, não apenas ficaram evidentes as opções metafísicas das ciências empíricas, mas também ficou claro que discussões a respeito dos fundamentos não podem ser conduzidas em uma disciplina realmente desprovida de elementos metafísicos. É claro que cada um tem a opção de evitar essas discussões por razões pragmáticas. Mas não há qualquer razão imanente à ciência para descartar a metafísica como velharia inútil. Mais ainda: não há qualquer critério racional para uma exclusão obrigatória da metafísica do discurso racional. Como disse há anos Wolfgang Stegmüller, extraindo uma consequência da autocrítica do Círculo de Viena, "só se pode lutar contra a metafísica com outra metafísica". ${ }^{33}$

A partir dessa conclusão, seria de esperar-se que a disputa em torno da metafísica tivesse acabado gradativamente. Sobretudo depois que certas experiências intelectuais do nosso século não mais permitem esperar que a metafísica seja suplantada pela crítica ou por teorias alternativas. Heidegger não só expressou, mas sua vida mostrou que a metafísica não pode ser "descartada" como uma opinião. ${ }^{34}$ Em conferências, ele desde cedo reconhecia nela a "permanente companheira" da filosofia ${ }_{i}{ }^{35}$ mais tarde, ele as uniria e a definiria como parte da

33. STEGMÜLLER, W. Metapbysik, Skepsis, Wissenscbaft (1954). Berlin/New York, 1969, p. 452.

34. HEIDEGGER, M. Überwindung der Metaphysik. In: Vorträge und Aufsätze. Pfullingen, 1954, pp. 68, 95.

35. HEIDEGGER, M. Die Grundbegriffe der Metaphysik: Welt - Endlichkeit - Einsamkeit. In: Gesamtausgabe, vol. 29/30. Frankfurt am Main, 1983, p. 85. 
natureza do homem historicizado. Que este tivesse por marca o esquecimento do ser era algo que ele atribuía então à metafísica; consequentemente, via nela a "necessária maldição do Ocidente", uma maldição que se completaria com o fim do homem moderno. ${ }^{36}$

A profecia filosófica de Heidegger depende de condições que residem no futuro; ${ }^{\prime}$ logo, não se pode julgar a veracidade de seu diagnóstico. No entanto, os esforços por ele dispendidos para pensar o impensável fim da metafísica deveriam servir como uma advertência. Antes que a metafísica pereça, tem de morrer todo o resto daquilo que o nosso mundo e nós mesmos significamos para nós. ${ }^{37}$ A metafísica só poderia perder o seu sentido com a destruição completa da milenar imagem de mundo em que nossa autoimagem está inserida. Só quem se desfizesse de todos os princípios poderia deixar a metafísica para trás. Adorno, também aqui muito próximo do adversário visado, propõe um pensamento micrológico que implode os "conceitos superiores de subsunção" e, assim, liberta o singular, que estava sob os princípios, para si mesmo. Tal pensamento, acreditava ele, seria "solidário com a metafísica no momento de sua ruína". ${ }^{38}$ Segundo Heidegger, isso também não seria suficiente: a libertação da metafísica leva tão somente a um esquecimento que, por seu turno, não oferece nada mais forte do que o silêncio. Quem declara a morte da metafísica a mantém ainda mais presa à vida.

O diagnóstico histórico-epocal de Heidegger bate inteiramente com a demonstração de Stegmüller: na medida em que mantemos nossa relação com o mundo sob pretensões de fundamentação, não conseguimos escapar da metafísica. O mais surpreendente é que não param de aparecer novos argumentos para tentar provar seu fim definitivo.

Não se deve esquecer, contudo, que uma grande parte da filosofia contemporânea não toma parte nas especulações sobre o fim da metafísica. Isto vale não apenas para alguns importantes representantes da filosofia alemã do Pós-Guerra, ou para os teóricos que estão à frente das modernas ciências naturais, mas também para os mais influentes filósofos do âmbito anglo-saxão. A continuidade da metafísica se mostra, nesses autores, na sobrevivência de problemas que não

36. HEIDEGGER, M. Überwindung der Metaphysik, p. 73.

37. Idem, p. 67.

38. ADORNO, T. Negative Dialektik. Frankfurt am Main, 1966, p. 398. 
perderam o seu sentido porque nós ainda nos interessamos por eles com vistas à concatenação e à unidade de nosso saber. Aqui não é tão importante se ainda existe ou pode existir "a" metafísica, mas apenas se pergunta o que é, em geral, uma coisa, uma pessoa, uma lei da natureza, uma ação ou um conhecimento - sob a condução, naturalmente, do saber disponível no presente. Para marcar a diferença em relação a teorias mais antigas, eventualmente são empregados novos atributos. Em conexão com Strawson, fala-se, por exemplo, em "descriptive metaphysics" ou "revisionary metaphysics", sem delimitar com clareza, contudo, as fronteiras que a separam das questões ontológicas ou especulativas herdadas da tradição. ${ }^{39} \mathrm{O}$ problema científico decisivo não reside aqui em saber se a argumentação é metafísica ou não, mas se a argumentação é boa: "If there are no good metaphysical arguments there is no good metaphysics ${ }^{\prime \prime 4} .41$

Já Gerold Prauss, anos atrás, lembrou a diferença qualitativa existente entre a boa e a má metafísica. ${ }^{42}$ Mas ela não parece suficiente para muitos teóricos modernos. Eles certamente querem também ser bons; mas algo só lhes parece bom quando é novo. Onde o novo

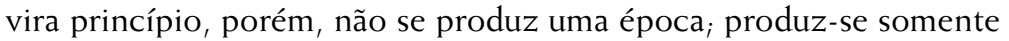
uma moda. O princípio da autossuperação, que move a modernidade, oculta o perigo de trocar o importante pelo novo. Também para a filosofia há riscos aqui contra os quais Kant, de modo paternal, já advertia: "Criar novas palavras onde a língua não tem carência de expressões para conceitos dados é um esforço infantil para destacar-se em relação à maioria não por meio de novos e verdadeiros conceitos, mas de um novo pano sobre o velho vestido". ${ }^{43}$ Pendurar um novo manto sobre a metafísica, ou mandar a filosofia ao mundo com as novas vestes do imperador, não poderia ser menos infantil.

\section{A metafísica em Habermas.}

Na mais recente resposta a Dieter Henrich, Habermas faz duas objeções contra a metafísica: a primeira se baseia em uma construção

39. STRAWSON, P. Individuals. London, 1959.

40. Se não há bons argumentos metafísicos, não há boa metafísica. (N. do T.)

41. HAMLYN, D. Metaphysics. Cambridge/Mass, 1984, p. 10.

42. PRAUSS, G. Einleitung in die Erkenntnistheorie. Darmstadt, 1980, p. 8 e ss.

43. KANT, I. Kritik der praktischen Vernunft. Ak.A., vol. 5, p. 10. 
histórica segundo a qual o pensamento metafísico pertence a uma época que se tornou ultrapassada. A segunda está diretamente ligada a essa construção, mas possui uma ênfase metodológica e se baseia na tese de que, segundo o padrão falibilista hoje vigente, enunciados metafísicos não podem mais ser legitimados cientificamente. Ambas as objeções são suficientes, segundo Habermas, para decidir se devemos abandonar o caminho tortuoso da metafísica. Pois o restante de sua crítica, dirigida à filosofia da subjetividade de Henrich, não diz nada contra a metafísica. Pelo contrário: com sua crítica ao dualismo e ao princípio da subjetividade, Habermas se movimenta ele próprio no âmbito do pensamento metafísico. Mesmo que fosse procedente a reconstrução linguístico-pragmática da autoconsciência, por ele perseguida, permaneceriam válidas as questões sobre o estatuto e o alcance dessa teoria. Além disso, as funções elementares da autoconsciência humana no contexto do agir e do saber não seriam eliminadas com a reconstrução. Teríamos, como sempre, de lidar com fato de que ela significa tudo para nós. E é difícil entender como Habermas pretende escapar às problemáticas metafísicas mantendo a pretensão de referir-se filosoficamente ao "todo da práxis da vida".

Habermas deu uma nova expressão a essa pretensão em seu primeiro texto contra Henrich: "A filosofia tem de tornar possível uma vida 'consciente', iluminada por uma autocompreensão reflexiva e, em um sentido não disciplinar, 'controlada'"'.44 Dificilmente se poderia exprimir com mais clareza o vínculo com o ideal autárquico da antiguidade. A filosofia como forma de acentuar conceitualmente a autodeterminação humana: juntam-se nesse objetivo não apenas Platão e Aristóteles, mas também Hobbes e Kant. Nessa tradição, ninguém se preocupa em colocar "consciência" e "autocontrole" entre aspas. Se os apóstrofos deveriam indicar que há problemas aqui, não se pode marcá-los com suficiente clareza. Desde Sócrates, afinal, todas as questões da filosofia giram em torno da possibilidade do autoconhecimento e do domínio racional. O conceito do filosofar moderno esboçado por Habermas se coloca, portanto, na tradição de onde brotam também as grandes questões metafísicas. Uma certa ruptura ocorre, de fato, naquela tradição, ainda jovem, que busca

44. HABERMAS, J. Metaphysik nach Kant, p. 430. 
remeter tudo ao ideal da completa "ausência de dominação". Mas isso não deve interessar-nos aqui. ${ }^{45}$

$\mathrm{O}$ quanto Habermas se sente de fato ligado à tradição, em suas pretensões filosóficas, deduz-se de suas afirmações sobre não ser possível se furtar nem às "questões incontornáveis de orientação de mundo canonizadas por Kant", nem às "velhas verdades" da metafísica.. A filosofia teria de manter vivo o "sentido de humanidade" e, assim, garantir que o homem se descubra no humano: "Todos têm de reconhecer-se em tudo aquilo que tem o rosto do humano". ${ }^{46} \mathrm{O}$ filósofo tem de interpretar o contexto em que vive com os seus semelhantes e, neste papel, não deve envergonhar-se da acusação de ser um "mediador de sentido". Esta é uma expressão ousada, que corresponde inteiramente à atitude científica e cultural-crítica de Habermas. Ela deixa claro, de um modo bastante simples, que o filósofo não pode prescindir da categoria de "sentido". Como intérprete da práxis da vida, ele não apenas precisa empregar conceitos como "mundo", "efetividade", "consciência" ou "eu", como tem ainda de explicar o que eles significam para aquele que os utiliza.

Não podem restar dúvidas de que essa é uma tarefa clássica da filosofia, ao menos no contexto do pensamento moderno. Não é muito nítido, portanto, como deveria desaparecer o caráter metafísico ligado às "questões inafastáveis" e às "velhas verdades". Habermas acredita que isso aconteceria inevitavelmente através da "apropriação crítica", isto é, através de um teste de alta precisão "no cone de luz, cada vez mais estreito e agudo, daquilo (...) que pode, com boas razões, iluminar os filhos e filhas da modernidade a esse respeito". ${ }^{47}$ À primeira vista, porém, não se consegue perceber o que isso traria de fundamentalmente novo: a "apropriação crítica" é o procedimento da filosofia moderna desde o princípio, e cada geração acreditou, desde então, oferecer padrões mais precisos para isso. Para Habermas, contudo, parece não tratar-se apenas de uma crítica mais aguda e de maior precisão, mas de uma mudança fundamental capaz de conduzir

45. Gerhardt, V. Recht und Herrschaft. Zur gesellschaftlichen Funktion des Rechts in der Philosophie Kants. In: Rechtstheorie, 1981, pp. 53-94.

46. HABERMAS, J. Metaphysik nach Kant, p. 430.

47. Idem, ibidem. No mesmo sentido, cf. HABERMAS, J. Die Philosophie als Platzhalter und Interpret. In: Moralbewusstsein und kommunikatives Handeln. Frankfurt am Main, 1983, p. 9-28. 
a uma "transformação de sentido" das velhas verdades. Também em suas duas objeções fundamentais contra a metafísica Habermas apela a essa mudança.

Na primeira objeção, Habermas se apoia na já não tão nova lei dos três estágios da história da filosofia: a sequência dos "paradigmas" "ontológico", "mentalista" e "linguístico". Trata-se de um modelo histórico que amplia a "virada crítica", inaugurada por Kant, para abarcar o "linguistic turn", mas que não fixa no ano de 1781 o ponto de virada do tipo de fundamentação ontológico para o mentalista. Herbert Schnädelbach, a quem Habermas recorre, situa a origem da mudança de paradigma do ser para a consciência já no antigo ceticismo, e apresenta Descartes como um típico representante disso antes de mostrar os elementos essenciais do novo pensamento no exemplo da filosofia transcendental de Kant. ${ }^{48}$ Ernst Tugendhat, que Habermas também designa como seu informante, divide a história da lógica segundo o mesmo esquema. Ele não denomina "mentalista" o segundo paradigma, e sim "psicológico"; mas Kant também é, para ele, o principal representante desse tipo de esclarecimento que teria começado a articular-se na lógica de Port Royal. ${ }^{49}$

A distinção dos três tipos de fundamentação tem uma grande plausibilidade - tanto teórica quanto histórica - e pode ser bastante útil como hipótese. Mas não se deve esquecer as desvantagens desse modelo: aquilo que nele aparece como abandono de paradigmas contrastantes já era, na autocompreensão dos filósofos, uma forma de interpretar as posições teóricas mais antigas à luz de novas experiências; isto vale particularmente para a passagem à segunda fase, na qual o pensamento ontológico não cessa, mas é simplesmente submetido a outros critérios. A exclusão teórica e histórica do paradigma mentalista é então pouco precisa: os momentos psicológico, metodológico e transcendental são equiparados; e o estatuto do "mental" permanece obscuro: ele é pensamento (aquilo que se mostra em conceitos), consciência (aquilo que acompanha todas as representações) ou experiência de si (aquilo que sei sobre mim a cada caso)?

48. SCHNÄDELBACH, H. Philosophie. In: MARTENS, E. e SCHNÄDELBACH, H. (orgs.) Philosopbie. Ein Grundkurs. Reinbeck, 1985, p. 46 e ss.

49. TUGENDHAT, E. e WOLF, U. Logisch-semanthische Prpädeutik. Stuttgart, 1983, p. 9 . 
Uma outra desvantagem é que ainda sabemos relativamente pouco sobre as consequências da mais recente mudança de paradigma. Em vista da autocrítica da filosofia analítica da linguagem, que se tornou mais clara nesse meio tempo, é duvidoso se a guinada em direção à linguagem trouxe mesmo o esperado ganho em termos de clareza metodológica. É fato que muitas questões podem ser analisadas com maior precisão. Mas não são estas as questões que sempre aparecem de novo à filosofia? Quando Wittgenstein afirma que um problema filosófico tem a forma "eu não entendo disso", ${ }^{50}$ ele não apenas está mais próximo de Kant e Sócrates do que a mudança de paradigma permitiria suspeitar, como articula uma compreensão do mundo a um só tempo "mentalista" e "ontológica", sem a qual a tradição filosófica não poderia ser compreendida por ele, nem ele por nós.

Se tentamos entender esse contexto particular, deparamos com o papel fundante da autoconsciência, que claramente não se deixa reduzir a um paradigma filosófico. A autoconsciência não é uma instância que só se tenha formado sob as formas de comércio do capitalismo burguês, para então oferecer, por um certo tempo, um acesso autônomo à práxis da vida. A filosofia como um todo é antes uma realização da autoconsciência humana, e é somente por isso que podemos entender-nos sobre as condições iniciais e os estágios de desenvolvimento do pensamento filosófico. Na medida em que ainda acreditamos compreender o que se passa na referida mudança de paradigma, nos colocamos - graças à reflexão autoconsciente - para além dela. Isto se mostra, por exemplo, no fato de que, devido à compreensão de nós mesmos que se tornou possível nesse meio tempo, temos razões para duvidar se os representantes das grandes concepções filosóficas eram mesmo tão limitados como, querendo destacar nossa própria época histórica, nós gostaríamos. Platão e Kant, em todo caso, podem ser caracterizados de tal modo que os filhos e filhas da modernidade poderiam contá-los também entre seus pais.

O que significa então o modelo dos três paradigmas para a metafísica? Habermas pressupõe que ela, como "a ciência do universal, imutável e necessário", só tinha direito de existência no registro dos paradigmas ontológico e mentalista. ${ }^{51}$ Aparentemente, ele a toma por

50. WITTGENSTEIN, L. Pbilosopbische Untersuchungen. Frankfurt am Main, 1960, p. 345 (§ 123).

51. HABERMAS, J. "Metaphysik nach Kant", p. 428. 
não problemática nesse contexto de fundamentação porque a necessidade e a universalidade podem ser aí referidas a um fundamento pensado como substancial: no paradigma ontológico a essência do ser, no mentalista a essência da consciência. Uma vez que, após a virada analítico-linguística, os fundamentos objetivos e conceituais da necessidade e da universalidade caem por terra, não se pode mais - esta é a conclusão - falar em uma metafísica científica neles baseada.

Deixemos por ora de lado a circunstância de que essa conclusão não faz jus à efetiva complexidade dos conceitos e objetos da ontologia - seja da clássica seja da crítica - e, naturalmente, também não leva em conta a carência de justificação que a metafísica já trazia consigo muito antes de Kant. Desconsideremos, portanto, a inofensividade atribuída por Habermas aos problemas da velha metafísica: permanece questionável, ainda assim, se a possibilidade da metafísica deve ser vista hoje como dependente das respostas já dadas. A fundação da universalidade e da necessidade por meio de uma substância pensada como análoga a um objeto, ou de uma elaboração apriorística por categorias, são modelos de solução inscritos no âmbito de concepções metafísicas determinadas. É justamente isso que a interpretação explicação da história da filosofia segundo o modelo dos paradigmas pode deixar claro. Mas o modelo histórico-científico das fases só conserva seu sentido se, quando da derrocada de uma concepção até então considerada abrangente, a disciplina em que ela era reconhecida não se torna obsoleta. A mecânica quântica colocou a mecânica de Newton em questão, mas não a física enquanto tal. $\mathrm{O}$ mesmo vale para a mudança de paradigma na metafísica. Somente se se pudesse mostrar que ela se esgotou por inteiro junto com as respostas específicas historicamente dadas se poderia justificar a conclusão da parte ao todo.

Mas a conclusão de Habermas é questionável independentemente dos conceitos histórico-científicos de ordem: ela só é convincente caso se aceite que a tarefa da metafísica é aquela que ele lhe atribui. Isto, porém, é algo que Habermas não consegue demonstrar - como é usual nas ciências - a partir da referência a um campo de objetos ou problemas, mas sim através de soluções já há muito conhecidas e hoje não mais convincentes. Com o recurso a esse procedimento, não é difícil vincular uma disciplina a um nível antigo de conhecimento para, então, recorrendo a novas descobertas, declará-la superada. Se uma ciência é definida por aquilo que gerações anteriores sabiam sobre seus objetos, a sua transformação em peça de museu decorre por si mesma. Mas o que de fato garante a continuidade das disciplinas não é nem o 
saber tradicional nem o procedimento então praticado, mas sim as problemáticas que se desenvolvem com o progresso do saber. Isto vale para todas as ciências, inclusive a filosofia. Somente com a metafísica, se Habermas tiver razão, deve ser diferente.

Esse tratamento diferenciado da metafísica demandaria uma justificação, sobretudo porque o problema dos enunciados universais e necessários permanece vivo. Não estaremos indo muito longe se contarmos as questões da fundamentação lógica, do significado semântico e do sentido pragmático da universalidade conceitual entre os problemas prioritários da contemporânea filosofia analítica da linguagem. Na medida, porém, em que permaneçam vivos os problemas da designação universal e da significação prática, também se recolocam aí as velhas questões da filosofia. Com relação a isso, bem lembrou Schnädelbach, na observação final ao paradigma linguístico, que, "via de regra, a filosofia analítica da linguagem não soluciona problema algum..."52

Em sua Teoria da ação comunicativa, Habermas mostrou enfaticamente o quanto leva a sério as questões de fundamentação e validade da universalidade teórica e prática. Em vista de sua forte recusa da metafísica, é de admirar-se o quanto ele entra aí em problemáticas herdadas da tradição. Ele tem a pretensão explícita de investigar os "conceitos fundamentais" em que a racionalidade das imagens de mundo se baseia. Ele se recusa, é verdade, a empregar o velho título da "ontologia" para esse empreendimento - mas não porque a ontologia seja muito universal, e sim porque não seja universal o suficiente! Para ele, a ontologia é excessivamente limitada a uma "forma específica de referência ao mundo", a saber, à "referência cognitiva ao mundo do ente" ${ }^{153}$ Ele gostaria de dar validade, além disso, à referência ao "mundo social e subjetivo", e explica que a novidade de uma teoria da ação comunicativa estaria nessa pretensão ampliada.

Deixemos em aberto, por ora, se essa pretensão se justifica em termos históricos; que a metafísica procure pelo menos desde Kant entender a referência ao "mundo subjetivo" é algo que Habermas absolutamente não questiona em outros contextos; e que a natureza pública e autônoma da razão talvez já esteja mais atrelada ao mundo político e social em Kant do que Habermas poderia compreender

52. SCHNÄDELBACH, H. Philosophie, p. 75.

53. HABERMAS, J. Theorie des kommunikativen Handelns, vol. 1, p. 75. 
através da "comunicação" é uma questão aberta à interpretação. Para uma avaliação do alcance de sua crítica à metafísica é suficiente considerar que ele pretende ampliar transcendental-filosoficamente a ontologia clássica, integrando-a assim à tarefa clássica da metaphysica generalis, e ainda assim acredita estar inteiramente liberto das questões metafísicas.

O mesmo se poderia dizer sobre a relação de Habermas com os grandes problemas da metaphysica specialis. Embora se expresse aqui de maneira mais contida, ele considera Deus, o mundo e a alma como temas necessários e legítimos da filosofia moderna quando assume a pretensão de trazer a "herança das religiões à profanidade" com meios filosóficos. ${ }^{54}$ No que diz respeito ao conteúdo, portanto, ele considera a filosofia em toda a sua amplitude. É apenas na sua autoapresentação científica que ele se reduz à posição de um teórico da sociedade que faz a mediação entre as disciplinas; e que, coerente com sua confissão marxista, só gostaria de conceder ao pensamento filosófico o estatuto que atribui à economia política. Isto conduz às peculiares refrações de seu pensamento. Se não houvesse nele tanta boa herança aristotélica e kantiana, Habermas deveria ser denominado, em simetria com a sua própria forma de fazer polêmica, um neomarxista cientificamente decaído. Mas estes rótulos são empobrecedores e dizem pouco. Continuemos, pois, a reconhecer nele um filósofo de nível ${ }_{i}$ um filósofo que, corrigida a primeira objeção, também poderia ser denominado, com justiça, um metafísico.

A primeira objeção contra a metafísica - a histórica - não apenas se mostrou em geral pouco consistente, mas, além disso, não encontra qualquer sustentação no próprio projeto teórico de Habermas. Resta então o segundo argumento, o metodológico, do qual já afirmamos que está intimamente ligado à avaliação que Habermas faz do desenvolvimento histórico da filosofia. É digna de nota, aqui, a mistura de uma reserva crítico-ideológica com um postulado metodológico: Habermas assegura que a metafísica clássica teria reclamado para si um "acesso privilegiado a visões da essência"; , hoje, pelo contrário, nós disporíamos somente de um "saber falível". 55

A contraposição deveria dar expressão a uma modéstia científica que Habermas já alegava em sua principal obra. Mantendo-se fiel à

54. HABERMAS, J. Kleine politische Schriften. Frankfurt am Main, 1981, p. 489.

55. HABERMAS, J. Metaphysik nach Kant, p. 434. 
delimitação das pretensões de conhecimento da velha Escola de Frankfurt, ele afirmava aí que uma teoria crítica da sociedade tem de evitar a avaliação geral e o julgamento normativo de "totalidades, formas de vida e culturas, de contextos de vida e épocas em seu todo". Qualquer tipo de "fundacionismo" pertenceria à história da filosofia; "imagens de mundo" seriam tão obsoletas quanto todas as tentativas de dar um fundamento transcendental às "grandiosas unilateralizações que trazem a assinatura da modernidade". ${ }^{56}$

Isso soa verossímil após o abandono de uma grande tradição. Se não é mais permitida nenhuma interpretação da natureza e da história, e a pergunta pela vida boa se tornou sem sentido, estamos aparentemente tão libertos da metafísica quanto da filosofia - pressupondo-se que esse abandono não esteja fundado em um argumento universal. Mas é exatamente isso que Habermas faz, e, muito consequentemente, situa nessa fundamentação a finalidade da filosofia ainda remanescente. Nesta determinação de uma finalidade, porém, retorna em toda a sua abrangência a tarefa clássica da filosofia. A filosofia, diz-se aí, consiste a partir de agora em um "autoentendimento" sobre o caráter do saber moderno, e teria como tarefa específica perguntar-se pela unidade da razão na teoria e na prática. ${ }^{57}$ Não se nota aqui a referida limitação do horizonte temático; nem mesmo a terminologia é particularmente nova. Pois quando é que a filosofia foi algo diverso de um autoentendimento do homem sobre aquilo que ele sabe? Não podem as questões da filosofia ser todas reunidas sob a questão da unidade da razão? E mesmo que perdêssemos de vista essa tradição: sobre o pórtico de entrada do nosso saber reencontram-se todos os problemas da natureza e da história, e a razão, concebida para a unidade, se esforçará para que eles atinjam totalidades. Onde quer que se encontre um todo, porém - como, por exemplo, no todo de uma vida humana -, não está longe daí o conceito do bem.

Como fica então a acusação de que a teoria filosófica tradicional não teria adotado o critério da falibilidade? Literalmente falando, pode haver algo correto nisso; os padrões do conhecimento científico se elevaram consideravelmente no século $\mathrm{XX}_{i}$ também se pode medir hoje por ele a teoria tradicional, que ainda não conhecia tais critérios. Mas se com isso se quiser dizer que a metafísica não apresentava suas

56. HABERMAS, J. Theorie des kommunikativen Handelns, vol. 2, pp. 584 e 262.

57. Idem, p. 584. 
ideias na forma de um saber passível de comprovação, então permanece obscuro a que tipo de metafísica Habermas de fato se refere.

Não pode ser a metafísica que hoje associamos aos nomes de Aristóteles, Leibniz ou Kant, pois essa metafísica se move no meio do saber, e um saber que está sempre à disposição. Ela era uma teoria baseada em fundamentos, argumentações e, naturalmente, também em fatos, e que, evidentemente, continha inúmeros erros; mas ela nunca vinha associada, em suas grandes concepções, à pretensão de não poder ser refutada por melhores argumentos. Somente quando as teorias filosóficas são reduzidas à dimensão de "imagens de mundo" - tal como faz Habermas - pode sustentar-se a oposição à "consciência falibilista". "Imagens de mundo só podem ser verdadeiras ou falsas" - e só podemos concordar com isso - "no sentido em que retratos o são"..$^{58}$ Mas teorias filosóficas podem ser verdadeiras ou falsas - mesmo antes de Habermas! Não fosse assim, não valeria a pena reconstruí-la e seria perda de tempo argumentar com um filósofo. A subestimação sistemática dos elementos epistêmicos e científicos da filosofia clássica se mostra também na inclinação de Habermas a vincular a metafísica mais fortemente à religião do que à ciência moderna. Ele coloca o "saber sagrado" da religião lado a lado com o "saber do mundo" da metafísica, mas estabelece uma clara fronteira entre este e o saber dos experts da cultura moderna. ${ }^{59}$ De um certo ponto de vista, nada há a objetar quanto a isso. Quando se trata de pretensões de totalidade e expectativas a respeito da vida, a metafísica está certamente mais próxima da religião do que das ciências particulares contemporâneas. Se devemos, no entanto, adotar o ponto de vista da falibilidade, é preciso traçar uma linha demarcatória clara entre a religião e a metafísica. Aqui, com efeito, a fé e o saber se separam. Já entre os antigos o logos se separava aqui do mito. A filosofia se apresentou desde o princípio como um saber. Segundo sua autocompreensão, ela abarcava tudo aquilo que se encaixasse sob pretensões epistêmicas. Foi por esta razão que ela pôde, no curso de sua longa história, dar origem a cada vez mais disciplinas particulares. Que ela não se tenha tornado mais pobre por isso; que nenhuma ciência - nem a física, nem a psicologia, nem a sociologia - lhe tenha tomado algo; que ela continue a ter o seu "objeto": tudo isso pode ser-lhe concedido sem que se tenha de considerá-la como

58. Idem, vol. 1, p. 92.

59. HABERMAS, J. Kleine politische Schriften, p. 489; Metaphysik nach Kant, p. 430. 
um dogmatismo semirreligioso. E isso tem muito a ver com a pretensão, também enfatizada por Habermas, a uma unidade entre teoria e prática.

Uma vez que essa unidade, segundo sua própria definição, não tem sentido como unidade de um objeto, a autoconsciência, que produz a unidade, passa ao primeiro plano de maneira particularmente clara. Habermas reconhece isso ao vincular o conceito racional de unidade aos processos de autoentendimento ${ }^{60}$ e, além disso, ao conferir um papel decisivo ao "saber intuitivo" 61 dos sujeitos competentes. A autoconsciência tem, portanto, uma função específica: ela dá acesso a todos os âmbitos do agir humano - à política, ao direito, à moral, à arte e... à ciência. Se nos servimos desse acesso com a disciplina da reflexão filosófica, isto quer dizer que o percorremos também com meios científicos. Por outro lado, nenhuma ciência particular deve ser impedida de abrir caminho com seu próprio instrumental. E mais: uma teoria filosófica torna-se vulnerável quando não se vale dos conhecimentos assim acumulados.

Desse ponto de vista, não se deve falar em um "privilégio" da filosofia. Ela tem apenas uma inevitável vantagem funcional em virtude de sua pretensão ao autoentendimento e à unidade conceitual ${ }_{i}$ uma vantagem que, em conformidade com a sua tradição, ela tem de pôr à prova com meios científicos - adequados, naturalmente, ao nível de conhecimento de sua época.

Nessa sua tarefa geral, a filosofia não está em concorrência com a pesquisa das ciências particulares, já que, em sua abrangente problemática, ela não pode ser reduzida a uma questão específica. No entanto, ela pode ser forçada a consideráveis revisões por conhecimentos das ciências particulares, pois, sobretudo em suas mais elevadas reflexões metafísicas, ela é tão somente uma crítica de teorias dadas e uma interpretação de conhecimentos particulares no interesse de uma vida compreendida em termos universais e racionalmente conduzida. E não é uma filosofia concebida obstinadamente como "indicadora de lugar" quem defende esse interesse em uma compreensão universalista e em uma condução racional da vida contra um saber científico melhor $_{i}^{62}$ é apenas e tão somente o ser humano quem tem esse inte-

\footnotetext{
60. HABERMAS, J. Theorie des kommunikativen Handelns, vol. 2, p. 584.

61. Idem, p. 562.

62. Cf. HABERMAS, J. Philosophie als Platzhalter und Interpret.
} 
resse e, por isso, segue sempre a levantar as velhas questões filosóficas. E, se percebo corretamente, ele o faz sem desprezar os conhecimentos e métodos da ciência moderna.

Saber falível e consciência filosófica estão tão próximos um do outro quanto a pesquisa científica e a metafísica: eles somente se juntam na consciência de um ser humano que se interessa pelos fundamentos de seu saber e de seu agir $e$ que só pode reconhecer como fundamento aquilo que ele próprio assim compreende. - Esta é a premissa simples que Habermas pretende denunciar como "privilégio", mas de que ele próprio precisa, como qualquer outro, para fundar as abrangentes pretensões de conhecimento de sua teoria - cujos vínculos com a tradição racional do pensamento filosófico são tão fortes.

$\mathrm{Na}$ resposta a Dieter Henrich, Habermas menciona a "relação ambígua" de Kant com a metafísica ${ }^{63}$ Infelizmente, ele não diz onde enxerga essa ambiguidade - se na crítica de Kant à metafísica tradicional, se na busca de critérios para uma metafísica que esteja à altura de padrões científicos, ou se na confiança de Kant nessa disciplina, pela qual ele teria o destino de "ser apaixonado" ${ }^{64} \mathrm{Eu}$ admito perceber em tudo isso uma consciência do problema da metafísica, mas não uma ambiguidade. Parece-me antes que é o próprio Habermas quem se expõe ao perigo de uma ambiguidade, na medida em que desperta expectativas metafísicas com a sua crítica e, querendo não ter mais nada a ver com o nome da metafísica, não faz outra coisa senão praticar metafísica em sua teoria.

\section{Tradução de Fernando Costa Mattos}

63. HABERMAS, J. Metaphysik nach Kant, p. 428.

64. KANT, I. Träume eines Geistersebers, Ak.A., vol. 2, p. 367. 
